NBER WORKING PAPER SERIES

\author{
DOES WELFARE PLAY ANY ROLE \\ IN FEMALE HEADSHIP DECISIONS?
}

Hilary Williamson Hoynes

Working Paper No. 5149

\author{
NATIONAL BUREAU OF ECONOMIC RESEARCH \\ 1050 Massachusetts Avenue \\ Cambridge, MA 02138 \\ June 1995
}

A previous version of this paper was circulated under the title "Female Headship and AFDC Benefits: State Effects or Welfare Effects?" The current version of the paper represents a substantial revision and broadening of the material over the earlier version. I have benefitted from discussions with Anne Case, Nada Eissa, Bruce Meyer, Robert Moffitt, Tom Mroz, Jim Powell, Paul Ruud, Glenn Sueyoshi and seminar participants at Berkeley, Michigan, Northwestern, San Diego, the Institute for Research on Poverty Workshop and the NBER Summer Institute. Gary Painter provided excellent research assistance. Financial support was received from the National Institute for Child Health Development, the Institute for Industrial Relations, the Institute for Business and Economic Research, and the Committee on Research at Berkeley. Computing support was provided by the Econometrics Laboratory at UC Berkeley. This paper is part of NBER's research program in Public Economics. Any opinions expressed are those of the author and not those of the National Bureau of Economic Research.

(c) 1995 by Hilary Williamson Hoynes. All rights reserved. Short sections of text, not to exceed two paragraphs, may be quoted without explicit permission provided that full credit, including (c) notice, is given to the source. 


\title{
DOES WELFARE PLAY ANY ROLE \\ IN FEMALE HEADSHIP DECISIONS?
}

\begin{abstract}
During the last thirty years, the composition of white and black families in the United States has changed dramatically. In 1960, less than ten percent of families with children were headed by a single mother, while in 1990 more than twenty percent of families with children were female headed households. A large body of research has focused on the role of the U.S. welfare system, and in particular, the Aid to Families with Dependent Children (AFDC) program, in contributing to these dramatic changes in family structure. Most studies use cross-sectional data and identify the effect of welfare on female headship through interstate variation in the AFDC program. Recent research finds that controlling for state effects has a large impact on the estimated welfare effect. This paper examines why state effects matter for estimating the role of welfare in female headship decisions by examining the importance of individual effects and policy endogeneity. A natural explanation for why state effects matter is that the composition of the population across the states differs, and the composition is related to the generosity of the state's welfare program. If that is true, then controlling for individual effects should have the same result as controlling for state effects. Second, the endogeneity of AFDC policy is examined by including controls representing the determinants of state welfare generosity. The results show that after controlling for individual effects, there is no evidence that welfare contributes to increasing propensities to form female headed households for either whites or blacks. Further, the results suggest that welfare-induced migration among blacks leads to an upward bias in the estimated welfare effect in previous studies.
\end{abstract}

Hilary Williamson Hoynes

Department of Economics

549 Evans Hall, \#3880

University of California

Berkeley, CA 94707-3880

and NBER 


\section{Introduction}

During the last thirty years, the composition of families in the United States has changed dramatically. In 1960 , less than ten percent of families with children were headed by a single mother, while in 1990 more than twenty percent of families with children were female headed households (U.S. Bureau of the Census, 1961, 1991a). These trends are common to both white and black families, although the increase among black families has been more dramatic. There have also been sizable increases in the number of out of wedlock births and teenage pregnancies among blacks and whites. In 1989, fully two-thirds of all births among blacks were to unmarried mothers (U.S. House of Representatives, 1992).

One reason why this increase in the percentage of families headed by single women is of concern is because the economic well-being of single parent families is typically below that of twoparent families. In 1990 , the poverty rate among female headed households with children was $45 \%$ compared to the rate of $8 \%$ among two-parent families (U.S. Bureau of the Census, 1991b). Over half of all families in poverty are now accounted for by female headed households. This disproportionate representation of female headed households among the poor population has led to the term the "feminization of poverty". Not only are female heads of household more likely to be poor in a given year, but they are also more likely to have longer spells of poverty (Bane and Ellwood, 1986) and are disproportionately represented among the persistently poor (Duncan, 1984). There is evidence that these trends are being transmitted through generations as female children raised in female headed households are more likely to drop out of high school, have an out of wedlock birth, and become heads of household themselves (McLanahan, 1988). ${ }^{1}$

These trends have stimulated a large body of research exploring the potential explanations for

\footnotetext{
${ }^{1}$ One should be careful in interpreting these events causally. It may be that those women who become female heads of household are more prone to poverty than those who marry, and that even if they had married, they may still have a higher propensity to be poor.
} 
these striking changes in family structure. Much of the research has focused on the role of the U.S. welfare system on family structure decisions. The Aid to Families with Dependent Children (AFDC) program provides cash benefits primarily to single parents with children, and eligibility in the program is restricted to those families with both low income and low asset levels. ${ }^{2}$ In addition, all AFDC participants are eligible to receive benefits through the food stamp and medicaid programs. Because these benefits are generally not available to two-parent families, it is argued that the U.S. welfare system encourages divorce, separation and the delay of marriage and remarriage (for example see Murray, 1984). Other explanations for the increase in female headship over the last two decades include the reduction in the number of marriageable men (resulting in sex ratio imbalances) through high unemployment, incarceration and mortality rates (Wilson and Neckerman, 1986), the increase in female employment and the fall in relative wages between men and women. ${ }^{3}$

It is of policy interest to determine to what extent our welfare system contributes to the increasing number of female headed households. Becker $(1973,1974,1981)$ presents a model of marriage whereby women choose marriage (or female headship) by comparing the utility inside and outside marriage. An implication of this model is that higher AFDC benefits (generally available only outside marriage) will lead to higher rates of female headship. AFDC benefits are set at the state level and exhibit enormous variation across states. In 1991, maximum benefits for a family of three ranged from $\$ 694$ in California and $\$ 680$ in Connecticut, to $\$ 288$ in Indiana and $\$ 120$ in

\footnotetext{
${ }^{2}$ In some states, benefits are available to eligible two-parent families under the AFDC-Unemployed Parent (UP) program. However, the eligibility requirements are more restrictive. At least one parent in the two-parent family must have a history of a significant attachment to the labor market, and can not be working more than 100 hours per month. Despite the fact that 26 states provided benefits under the UP program in 1991, only $6 \%$ of the caseload were receiving benefits under the UP program. The Family Support Act of 1988 requires that all states set up UP programs by 1990 . Hoynes (forthcoming) examines the effects of AFDC-UP on labor supply and welfare participation and Winkler (1993) considers the effect of expanding the UP program on family structure.

${ }^{3}$ See Garfinkel and McLanahan (1986) and Ellwood and Crane (1990) for a summary of literature which explores the role of changes in labor markets on family composition. Espenshade (1985) provides a general overview of the determinants of trends in marital rates.
} 
Mississippi (U.S. House of Representatives, 1992). Women who live in states with relatively high AFDC benefits, therefore, should be more likely to choose female headship then women who live in relatively low benefit states.

This interstate variation in benefits forms the basis for estimating the effect of AFDC on female headship. As reviewed in Moffitt (1992), most studies use cross-sectional data and estimate a female headship equation as a function of individual characteristics, benefits, and, in some studies, other state characteristics. The results from this research are mixed. As summarized in Groeneveld et al (1983), the early literature found insignificant effects of the welfare system on family structure. More recent evidence implies that the welfare system has a positive and significant, yet modest, effect on the propensity to form female headed households (Danziger et al, 1982; Ellwood and Bane, 1985; Moffitt, 1990a; Hoffman et al, 1991; Schultz, 1994; Winkler, 1993).

There are three reasons why the welfare effect from these studies may be biased. First, social norms, cultural effects, and religious influences are likely to play an important role in family structure decisions, and are largely unobservable to the researcher. As discussed by Ellwood and Bane (1985), if these largely unobservable influences are correlated with the state welfare benefit, then, appealing to standard omitted variable bias arguments, the welfare benefit effect will be biased. For example, if the population in a given state believes strongly in the two-parent family, the state may not have much support for an AFDC program and, hence, offer low benefits. Or a state which is more accepting of non-traditional family structures may favor a higher level of support for female headed households. In a cross-sectional study you can not identify both state fixed effects and welfare effects. Formally, if welfare benefits are correlated with unmeasured state attitudes, estimates from these studies will be biased. If the unmeasured effects are positively (negatively) correlated with welfare benefits then the estimated welfare effect will overestimate (underestimate) the true effect. 
Two studies provide evidence that ignoring state effects can lead to incorrect conclusions about the impact of welfare on female headship. Ellwood and Bane (1985) include an estimate of the likely welfare benefit (instead of simply welfare benefits) by adjusting the benefit for the likelihood of receiving AFDC benefits if single parenthood is chosen. By creating intra-state variation in benefits, they estimate a benefit effect while controlling for state effects. Moffitt (1994) estimates a model of female headship using state fixed effects and controls for state AFDC benefits. He is able to identify both effects by pooling several cross-sections of the Current Population Survey. Moffitt finds that adding state effects changes the benefit effect for white women from positive and significant to negative and significant. Interestingly, for black women, the state effects did not matter.

A second potential problem is the endogeneity of state policy. Besley and Case (1994), using the example of worker's compensation benefits, explore the possibility that state policy is affected by political and economic conditions, and voter preferences. They argue that if these policy determinants are related to the variable of interest, their omission can lead to erroneous conclusions as to the importance of policy. While the determinants of state AFDC benefits have been examined (Darity and Myers 1983, Plotnick and Winters 1985, and Moffitt 1990b), they have not been incorporated in the empirical literature on the effects of welfare on family structure. If these policy setting variables are related to female headship, then omitting these variables may also lead to biased estimates of the AFDC effect. ${ }^{4}$

A third problem is the importance of omitted individual effects. There are important

\footnotetext{
${ }^{4}$ Besley and Case (1994) derive the bias that results from omitting these policy determinants under several standard models in the literature (e.g., fixed effect models and difference-in-difference models). They point out that controlling for observable determinants of policy may not be sufficient since unobservable determinants may be correlated with the error in the headship equation. They propose an instrumental variables approach to estimating the effect of policy on individual outcomes. In practice, they find it difficult to find good instruments for identifying the policy determination equation.
} 
determinants of individual family composition decisions, such as marriage and female headship, which are not observed by the researcher. It is possible that these omitted effects may be correlated with the generosity of AFDC benefits through selected migration over time. This would result in a correlation between welfare benefit levels and the distribution of the population with respect to the propensity to be a female head. This has not been examined in the literature.

This study takes as a starting point that omitting state effects may lead to a bias in the estimated effect of AFDC on female headship decisions. I explore why state effects matter for estimating the role of welfare in female headship decisions by examining the importance of individual effects and policy endogeneity. A natural explanation for why state effects matter is that the composition of the population across the states differs, and the composition is related to the generosity of the state's welfare program. The interpretation of the state effect in this case is some average of the attitudes of its population. If that is true, then controlling for individual effects should have the same result as controlling for state effects. Second, the endogeneity of AFDC policy is examined by including controls representing the determinants of state welfare generosity. To do this, data from the Panel Study of Income Dynamics (PSID) is used to estimate a model of female headship controlling for welfare benefits, characteristics of the woman, characteristics of the state, year effects, state effects, and individual effects. Pooled cross-sectional data allows for the identification of a welfare effect and a state effect. Panel data, by having repeated observations on persons over time allows for the identification of welfare, state and individual effects.

The results of the analysis imply controlling for unmeasured individual effects has a dramatic effect on estimates of the role of welfare in family structure. The bias in the estimated welfare effect for whites can be attributed to either omitted state or individual effects. After controlling for individual effects, there is no impact of either state fixed effects or other state variables on the estimated welfare effect. Among blacks, individual effects matter, but, consistent with previous 
studies, state effects do not. Overall, once the model is correctly specified to include individual effects, there is no evidence that welfare contributes to increasing propensities to form female headed households for either whites or blacks.

The rest of the paper is organized as follows. Section $\mathbf{2}$ briefly reviews the existing literature on female headship. Section 3 presents the economic model and empirical implementation. Section 4 discusses the data used in the analysis. Section 5 presents the results. Concluding remarks are provided in Section 6.

\section{Previous Evidence on the Role of AFDC on Female Headship}

There has been a great deal of research exploring possible explanations for the recent trends in the family structure in the U.S. The current discussion, however, is limited to summarizing the existing evidence on the effect of welfare programs on female headship. Other studies explore the role of welfare on the probability of divorce (Hoffman and Duncan, 1993; Dechter, 1992), remarriage (Hoffman and Duncan, 1988), subfamily formation (Ellwood and Bane, 1985; Hutchens et al, 1989), transitions to female headship (McLanahan, 1988), and out of wedlock childbearing (Ellwood and Bane, 1985; Plotnick, 1990; Duncan and Hoffman, 1990). ${ }^{5}$

The early literature on the effects of AFDC on female headship is based primarily on state, SMSA, or city level analyses. The results from this literature are mixed and find no compelling evidence that AFDC has a significant effect on female headship decisions. ${ }^{6}$ The more recent literature, using a variety of cross-sectional datasets, shows a significant and positive, but modest, effect of welfare on female headship. Danziger et al. (1982), used data from the Current Population

\footnotetext{
${ }^{5}$ For a summary of the literature on the effect of welfare on various measures of family composition, see Moffitt (1992).

${ }^{6}$ Reviews of this literature can be found in Groeneveld et al (1983), Bishop (1980), Wilson and Neckerman (1986), and Garfinkel and McLanahan (1986).
} 
Survey (CPS) and provide the first formalization and estimation of Becker's $(1973,1974,1981)$ model of marital formation. They estimated the earnings and income available in both marriage and female headship and found significant effects of AFDC. Schultz (1994) extends the work by Danziger et al. by modeling fertility as well as earnings and marital status. He finds a consistently positive effect of welfare on female headship for whites, but somewhat more mixed results for blacks. Studies based on a reduced form of Becker's model have also found significant effects of welfare on female headship. These studies typically model the probability of being a female head as a function of individual characteristics, and state characteristics (Moffitt, 1990a; Winkler, 1993). Because these studies rely on cross-state variation in the welfare benefits to estimate the welfare effect, they are likely to suffer from the three sources of bias due to omission of state and individual effects and controls for policy determination. If these unobservable effects are correlated with the benefit variable then, using standard omitted variable arguments, there will be a bias in the estimated welfare effect. $^{7}$

There is evidence concerning the importance of omitting state effects. The few studies that have attempted to correct for unmeasured state influences show significant effects on the estimated welfare effect. Ellwood and Bane (1985) were the first to raise the issue of the potential bias in the welfare estimate. They adjusted welfare benefits in the headship equation by the likelihood of participating in AFDC, if headship was chosen. This created intra-state variation in the benefit variable which then allowed them to estimate state fixed effects. ${ }^{8}$ While they considered many

\footnotetext{
${ }^{7}$ While this paper focuses on the female headship decision as the outcome variable, other outcomes such as divorce, separation, out of wedlock births, teenage pregnancy have been analyzed in this same framework. The following comments about the potential bias in the estimated benefit effect also apply to those studies.

${ }^{8}$ Ellwood and Bane used a two step procedure. They estimated an AFDC participation equation for all female heads of bousehold in the sample. The estimates from that equation were used to predict participation probabilities for each woman in the sample. The benefit variable in the female headship equation is then replaced with "likely" benefits by multiplying benefits by the estimated participation probability. Because this method relies on a sample of female beads of household to estimate the participation effect, any correlations between the participation decision and female headship decision could create a bias in the estimated participation probabilities. For example, if female
} 
outcome variables (divorce, female headship, out-of-wedlock childbearing) welfare was found to have the largest effect on the probability of living independently. Moffitt (1994) uses over twenty years of pooled cross-sectional data from the Current Population Survey to estimate a female headship model with fixed and random state effects. Controlling for unmeasurable state effects was found to diminish the role of welfare for whites but increase the estimated welfare effect for blacks. There has not been any examination of the importance of individual effects.

Darity and Myers(1983), Plotnick and Winters (1985) and Moffitt (1990b) examine the determinants of AFDC benefits. Plotnick and Winters (1985) consider the determinants of state-level AFDC benefits and find that higher benefits are associated with states with higher per capita income, higher density of the poor population, higher welfare recipiency rates, lower levels of illegitimacy among recipients, and lower food stamp levels. Darity and Myers consider a simultaneous model of female headship and benefit determination using annual time series data for the US. They find that after controlling for the endogeneity of benefits, AFDC does not influence marriage rates. ${ }^{9}$ Moffitt (1990b) found higher state income and lower food stamp benefits to be associated with higher AFDC benefits. ${ }^{10}$

\section{An Empirical Model of AFDC and Female Headship}

The fundamental theory of marital formation and dissolution was developed by Becker (1973, 1974,1981 ) and most empirical studies of family formation begin with some version of his model. Becker's model is based on the proposition that a woman will choose marriage when the economic

heads of household are more likely to participate in AFDC for unmeasurable reasons, then this method will overestimate the participation probabilities for married women.

${ }^{9}$ It is not clear how they identify the effects of AFDC since they did not indicate any instruments for the AFDC determination equation. The instruments for female beadship are unemployment rates and population ratios.

${ }^{10}$ The endogeneity of area policies have been examined in other applications. Besley and Case (1994) consider the effect of worker's compensation benefits on labor market outcomes, Rosenzweig and Wolpin (1986) consider the effect of family planning programs on health outcomes, and Poterba (1994) considers how states respond to periods of fiscal crisis. 
benefits (or utility) inside marriage exceed the economic benefits outside marriage. His theory implies that marriage is particularly advantageous if there is specialization between the partners. That is, one partner specializes in market work while the other specializes in home production. Implications of this model are that increases in the earnings or wages of the potential spouse will increase the probability of marriage while increases in any benefits available outside marriage (such as welfare benefits) will decrease the probability of marriage. Extensions of Becker's model show that an increase in the woman's wage can have an ambiguous effect on the probability of marriage. On one hand, an increase in earnings of the woman increases family income which can have a stabilizing effect on the marriage. But this increase in earnings also facilitates independence from the husband, which can lead to a decrease in marriage. ${ }^{11}$ Ross and Sawhill (1975) refer to these two effects as the income and independence effects.

In the spirit of Becker's model, consider the determinants of the discrete choice of female headship versus marriage. The utility function,

$$
U\left(F H, W^{f}, W^{m}, B, X\right)
$$

represents the maximum utility associated with choosing female headship $(F H=1)$ or marriage $(F H=0)$. Maximum utility associated with marriage is a function of the woman's wage, $W^{f}$, her potential spouse's wage, $W^{m}$, welfare benefits, $B$, and the woman's characteristics, $X$. In choosing female headship, the woman loses access to the potential spouse's wages $W^{m}$ but gains access to

\footnotetext{
${ }^{11}$ Becker focuses on the independence effect as the main implication of increasing women's labor market oppornunities. An increase in earnings of the woman implies that the gains to specialization are reduced which will have a negative impact on the probability of marriage.
} 
welfare benefits, $B .^{12}$ The woman then chooses the state with the highest utility. ${ }^{13}$

If $F H^{*}$ is defined as the difference in the maximal utility between the two states, then the woman then chooses female headship if $F H^{*}$ is greater than zero:

$$
\begin{gathered}
F H^{*}=U\left(1, W^{f}, 0, B, X\right)-U\left(0, W^{f}, W^{m}, 0, X\right) \\
F H= \begin{cases}1 & \text { if } F H^{*}>0 \\
0 & \text { otherwise }\end{cases}
\end{gathered}
$$

In order to evaluate the probability that a woman chooses female headship or marriage, we need to know the woman's wage and her spouse or potential spouse's wage. However, the difficulty is that we only observe a spouse's wage if the woman is married (and the spouse is working) and we only observe a woman's wage if she is working. If we assume that wages are a function of the woman's characteristics $(X)$ and labor market variables $(L)$ then we can replace both wage variables by their determinants. Therefore, the effect of earnings of the woman and her potential spouse enter implicitly through their determinants. ${ }^{14}$ While the results from this reduced form model can not

\footnotetext{
${ }^{12}$ The main benefits of the U.S. welfare system for families include cash benefits under the Aid to Families with Dependent Children Program and in-kind benefits through the Food Stamps and Medicaid program. In some circumstances, these benefits are available to two-parent families. While the empirical implementation will take this into account, the remainder of this theoretical discussion will assume, for simplicity, that benefits are available only to single mothers.

${ }^{13}$ This is a myopic model of marriage where the utility is re-evaluated each period. A dynamic model of marital status based on a search model is a matural extension, but has yet to be developed in the literature.

${ }^{14}$ Alternatively, if one is interested in determining the importance of labor market factors, both $W^{f}$ and $W^{m}$ need to be estimated. The approach used in the literature is to estimate a wage equation based on the sample of spouses of married women and to use those estimates to predict spouse's wages for the entire sample of women (Danziger et al, 1982; Schultz, 1994; Duncan and Hoffman, 1990; Hoffman et al, 1991). The covariates used to estimate the wage equation include characteristics of the wife, and local labor market variables. Estimating earnings or income in the counter-factual state, however, can be problematic. We only observe the wage of spouse for those women who are married and if there are unobservable factors that affect female headship which also affect the earnings of the potential spouse, then this method will yield biased estimates for the wage estimates. For example, if women who are married have higher marriage opportunities, then we will overestimate spouse's wages for female heads of household. While fully accounting for this correlation in the unobservable components requires estimating a simultaneous model, a two stage estimation method has been used (Schultz, 1994; Duncan and Hoffman, 1990).
} 
be used to determine the importance of changes in the employment and earnings of men and women, they are appropriate to explore the role of welfare benefits in the presence of regional or state effects. ${ }^{15}$

Assuming a linear form for the indirect utility function and adding an error term, the difference in utility becomes:

$$
F H_{i t s}^{*}=\beta_{0}+\delta_{1} B_{t s}+\delta_{2} U P_{t s}+\beta_{1} X_{i t s}+\beta_{2} L_{t s}+\nu_{i t s}
$$

where the subscripts its correspond to individual $i$ in period $t$ living in state $s$. Welfare benefits are captured through two variables: state level AFDC benefits $\left(B_{t s}\right)$ and a dummy variable indicating whether state $s$ offered AFDC benefits to two-parent families in period $t\left(U P_{t s}\right){ }^{16}$ Higher welfare benefits are expected to increase the probability of female headship. In about half the states, benefits are available to eligible two-parent families through the AFDC-UP program. All else equal, we would expect that by offering UP benefits, the economic gain to being a female head of household would be reduced. However, the eligibility rules are more restrictive for UP families and thus the program is not on par with the single mothers program. Labor market variables, which control for wage opportunities, are captured by $L_{t s}$.

The error term $\nu_{i t s}$ is specified as

$$
\nu_{i s t}=\lambda_{t}+\gamma_{s}+\alpha_{i}+Z_{t s} \eta+\epsilon_{i t s}
$$

where the $\lambda_{t}$ are year effects, $\gamma_{s}$ are state fixed effects, $\alpha_{i}$ are individual effects, and the $\epsilon_{i t s}$ are assumed to be iid errors. Year effects are included to capture any common trends in social norms

\footnotetext{
${ }^{15}$ This reduced form approach has been used frequently in the literature (Ellwood and Bane, 1985; Moffitt, 1990a; Moffitt, 1994; Winkler, 1993).

${ }^{16}$ In the empirical results, $B_{s t}$ is measured by the combined benefits through the AFDC, food stamps and Medicaid programs.
} 
and expectations or other determinants of marital decisions. The state effects capture time invariant factors that influence female headship which are shared by all residents of the state. The individual effects capture the unobserved factors at the individual level that do not change over time. The state variables, $Z_{s t}$, represent the possible determinants of state AFDC benefits.

If either the state effects or individual effects are correlated with the benefit variable $B_{s l}$, then omitting $\gamma_{s}$ or $\alpha_{i}$ will lead to a biased estimate of the welfare effect, $\delta_{1}$. It has been shown that the state effects are correlated with benefits, and the substantive results change when they are included (Ellwood and Bane 1985, Moffitt 1994). The focus in this study is to examine why state effects matter. One hypothesis that will be explored is that states differ in the composition of their population which is in turn correlated with the state benefit level. One interpretation of a "state" effect is that it represents an aggregation of the preferences of the state residents. ${ }^{17}$ If so, then controlling for individual effects should have the same impact (on the estimated welfare effect) as controlling for the state effects.' If families move over time, however, then the state effects will not necessarily capture the same influences as the individual effects. Therefore, if sufficient numbers of families move over the course of the PSID data (interstate migration is observed in the PSID), then individual effects can be identified independently of state effects.

A second hypothesis is that the state welfare policy is endogenous. In particular, suppose that state benefits are influenced by economic, demographic and political variables captured in $Z_{s t}$. Omission of these variables may also lead to a bias in the estimated welfare effect.

Most of the literature follows the approach in (4) but, because of the reliance on a single cross-sectional dataset, does not identify the components of the error structure in (5). In the current

\footnotetext{
${ }^{17}$ This was Ellwood and Bane's interpretation of the omitted state effects. Another interpretation is that state effects capture other characteristics of the state's welfare program not captured by $B_{s t}$ such as the availability of education and training services, conditions at the welfare offices, etc. Evidence to be presented later discounts the importance of the later interpretation.
} 
application, the use of panel data allows for the identification of both state and individual effects.

A linear probability model (LPM) is used to estimate the female headship equation using the error structure in (5). The error components are estimated as fixed effects using standard panel estimation procedures (for example see Tsaio 1986). The LPM model is used because of the infeasibility of estimating the probit or logit models with individual fixed effects for this application. ${ }^{18}$ The limits to using the LPM, however, are well-known (for example, see Maddala 1983). To check the sensitivity to the LPM assumption, some specifications of the model are estimated using a mixed logit model with state fixed effects and individual random effects (Heckman and Singer 1984). The likelihood function for the mixed logit model is presented in Appendix A. ${ }^{19}$

\section{Data}

The main data used for this analysis are drawn from the Panel Study of Income Dynamics (PSID). The PSID is a longitudinal dataset collected by the Institute for Social Research (ISR) at the University of Michigan which began in 1968 with a sample of about 5,000 households containing 18,000 individuals. All members (and descendants) of these original survey families have been reinterviewed annually such that by the twenty second year of the panel, more than 38,000 individuals have participated or are currently participating in the survey. All estimates presented here are based on the 1968-1989 (or Wave XXII) sample of the PSID. The original 1968 sample consists of two subsamples: a nationally representative subsample of 3,000 households (Survey Research Center or SRC subsample) and a subsample of 1,900 households selected from an existing sample of low

\footnotetext{
${ }^{18}$ Chamberlain (1980) shows that a fixed effects conditional logit model can be used to estimate individual fixed effects in a discrete choice model. The conditional likelihood approach implies that the fixed effects are identified by the switchers (e.g., those who transition between female head and non-female head status) in the dataset. In this application, the sample size of switchers is not sufficient to implement this approach.

${ }^{19}$ The mixed logit model can not be used to examine the hypothesis that omitted individual variables are driving the state fixed effect results because, by definition, the discrete distribution describing the individual effects is assumed to be independent of the covariates in the model.
} 
income and minority populations (Survey of Economic Opportunity or SEO subsample). To adjust for this nonrandom composition, the PSID includes weights designed to eliminate biases attributable to the oversampling of low income groups and to attrition. All results presented here use the weights provided by the PSID.

The estimation dataset includes all women aged 16-50 with children who are either married or household heads. The dependent variable in the empirical analysis is equal to one if the woman is a female head, and zero otherwise. ${ }^{20}$ An observation is created for each year that the woman satisfies this sample selection condition. The estimation dataset contains a total of 59,940 observations for 3,808 white women and 3,015 black women over the twenty-two period.

The PSID data is augmented with state level on welfare benefits, economic conditions, population characteristics, and political indicators. Two variables are used to describe the welfare benefits available in each state in each year. Benefits for AFDC participants are not limited to the cash transfers available under the program, but also include in-kind benefits through the Food Stamp and Medicaid programs. The benefit variable used in the analysis is equal to the combined cash value of benefits for a family of four from AFDC, Food Stamps and Medicaid. ${ }^{21}$ We also include a dummy variable equal to one if the state had an AFDC-UP program in the particular year. The

\footnotetext{
${ }^{20}$ Women who are cohabitating are assigned to the non-female head or married choice. Female heads include only those living without a spouse or partner. Note that there is some inconsistency in identifying subfamilies in the PSID. It is not until a woman "splits-off" and creates her own bousehold that she may be identified as a subfamily bead. For example, if a woman is living with ber parents at the start of the sample, and she has her own child, she is not identified as a subfamily head. However, if she leaves ber parent's household and then returns, she would be identified as a subfamily head from that point on. This could cause sample selection problems because we only include those women who leave their parent's household and then return.

${ }^{21}$ The total cash value of the three programs is assigned to be $70 \%$ of the maximum AFDC benefit plus the food stamp maximum benefit plus $36.8 \%$ of the average Medicaid expenditure. The medicaid benefit is calculated as the state's average Medicaid benefits (for AFDC recipients) for a family of four. The 70\% results from AFDC income being "taxed" in calculating the food stamp benefit. Moffitt and Wolfe (1992) found the cash value of Medicaid to be $36.8 \%$ of expenditures. The AFDC data came from unpublished tables from the Family Support Administration, Department of Health and Human Services. The food stamp data came from unpublished tables from the Food and Nutrition Service, Department of Agriculture. The Medicaid data was generously provided by Robert Moffitt. All benefits are assigned based on a standard family size (four persons) because of the potential endogeneity of fertility decisions.
} 
states that offer UP benefits tend to be higher benefit, higher caseload states. ${ }^{22}$ The state-level economic variables include the unemployment rate, average wage in manufacturing, per capita income, and statewide welfare participation rates. Demographic variables include the percent of the population that is over age 65 , and the percent that are children. The political variables include the party of the governor, and the party composition of the state senate and house. ${ }^{23}$

Weighted statistics for the sample data are summarized for white women in Table 1 and for black women in Table 2. There are a total of 35,517 observations for whites and 24,423 observations for blacks. Over the sample period, 14 percent of white women in the sample were female heads compared to 51 percent of blacks. The PSID data shows increasing trends in headship over the sample period where both whites and blacks saw a near doubling in the incidence of female headship over the period. Tables 1 and 2 show that female heads of household are more likely to have lower education levels, have smaller families, and live in an SMSA. Black women with children are more likely to have lower education levels and larger families than whites. Religion of the head is provided in the PSID which is likely to be correlated with headship status. The majority of black women are baptist while white women are more likely to be protestant or catholic. Female heads of household, especially blacks, are more likely to live in areas with higher unemployment rates, higher wages, higher state income, and greater republican presence in the state government.

Figure 2 presents average real benefit levels among our sample of women with children from the PSID. The AFDC guarantee has been declining in real terms over the entire period, although there has been a flattening of benefits since 1983. This real decline in benefits has been moderated

\footnotetext{
${ }^{22}$ Over the time period covered by the PSID, there was only minor variation in the number of states participating in the UP program. In 1968, 21 states offered AFDC-UP benefits. Through the mid-1970s state participation increased, then decreased in the early 1980s. State participation has increased since the early 1980s. The Family Support Act of 1988 mandates that all states extend AFDC-UP benefits by 1990 . See Hoynes (1993) for further description of the AFDC-UP program.

${ }^{23}$ These state data were generously provided by Anne Case.
} 
by growth in food stamps and medicaid as the combined cash value of the three programs increased somewhat until 1974 and have declined since. While increases in AFDC benefits generally have to be authorized by state legislatures, Food Stamp benefits are adjusted annually or semi-annually for changes in food prices. Using AFDC alone gives a deceptive picture of trends in the generosity of "welfare" because growth in one program can, to some extent, offset decline in another. In the empirical work that follows, the results are not sensitive to the definition of welfare benefits.

Comparing the trend in benefits to the trend in female headship in figure 1 , it appears that benefits tracked female headship quite closely until the mid 1970s. Since then, real benefits have declined while the headship rate has increased. This point has been made in the time series literature. However, other factors may have changed since the mid 1970s which may still leave a role for welfare.

In state fixed effects model, the welfare effect is identified by within state variation in benefits over time. Figures 3 and 4 illustrate that there are significant differences in the trends across the states. Figure 3 shows real AFDC benefits for four moderate to high benefit states with large welfare caseloads. Illinois was a very high benefit state in 1968 (fourth highest ranked state) and is now one of the lowest benefit states outside of the south (ranked 22rd overall). California was an average state in 1968 (ranked 23rd) but has risen to become one of highest benefit states by the end of the period. ${ }^{24}$ Figure 4 shows the trends for three low benefit states. While Mississippi has consistently been one of the lowest benefit states over the entire period, Texas has fallen from modest benefits (ranked 12th in 1968) to one of the lowest benefit states in the country (ranked 3rd above Alabama and Mississippi).

\footnotetext{
${ }^{24}$ During much of this period, California was the only major state where AFDC benefits were automatically adjusted for changes in the cost of living. Typically, benefits are set nominally by the state legislatures and benefits remain fixed in nominal terms for periods of several years.
} 


\section{Results}

This section presents estimates for the female headship model described in section 3 . The sample consists of all married women or female heads of household with children who are between the ages of 16 and 50. The dependent variable is equal to one if the woman is a female head, and equal to zero otherwise. Because headship patterns differ quite substantially for blacks and whites (Ellwood and Crane, 1990, Danziger et al, 1982; Hoffman et al, 1991; Moffitt, 1990a; Moffitt 1994), separate equations are estimated for white and black women. To account for non-random sample composition, all regressions are estimated using the sample weights. Standard errors are adjusted for arbitrary correlation over time using the correction of Huber (1967). The linear probability model is estimated accounting for heteroscedasticity due to the use of a discrete dependent variable in a linear model (Maddala 1983).

\section{Estimates for White Women}

Parameter estimates for the headship equation for white women based on the linear probability model are provided in table 3. Model (1) provides estimates for the basic model which includes welfare benefit variables, characteristics of the woman, labor market variables, division dummies, and time effects. Consistent with recent evidence, welfare benefits have a positive and significant, but modest, effect on female headship for white women. If AFDC benefits were increased by $\$ 100$, female headship would increase by 0.6 percentage points, an increase of about five percent. Contrary to expectations, living in a state that offers AFDC-UP benefits is estimated to have a positive (although insignificant) effect on female headship. ${ }^{25}$ The other covariates included in the model show that female headship is higher for younger women, with lower education levels, with older

\footnotetext{
${ }^{25}$ In UP states, benefits are potentially available both inside and outside of marriage. Consequently, it is possible that the effect of benefits on family structure will differ in states offering AFDC-UP benefits versus non-UP states. In results not shown, interacting the AFDC-UP dummy with the benefit variable results in the expected negative coefficient on the AFDC-UP dummy. This was also found by Winkler (1993).
} 
children, living in urban areas. Female headship also varies by religious affiliation-- relative to the omitted group of catholics-- jewish women have lower and those with no stated religion have higher propensities to be a female head of household. The effect of education and living in an urban area have particularly large effects. White women with less than high school education are more than twice as likely to be female heads than high school graduates. Living in an SMSA increases the female headship probability by 25 percent. $^{26}$ Unemployment rates and average wages are not important determinants of female headship outcomes. Time effects are included to control for changes in social norms, and show a consistent upward trend. These time effects are jointly significant at the 1 percent level.

The remaining models in table 3 examine the role of state and individual effects. Due to small sample sizes in some states, these results are estimated on a subset of the full sample, including 21 states for a total of 27,532 observations. ${ }^{27}$ The characteristics of the state sub-sample are presented in Appendix table B-1. Models (2) and (3) present specifications with and without division dummies. The welfare effect in this subsample is somewhat higher but the marginal effect for most other covariates are similar. Adding the fixed effects for the states, as presented in (4), substantially changes the estimated welfare effect. These results imply that the unmeasured state effects are quite influential as the estimated welfare effect changes from being positive and significant to being close to zero and insignificant. These state effects are jointly significant at the 1 percent level. To explore what causes this reversal, figure 5 plots the estimated state fixed effects against average welfare benefits for each of the states in the sample. The decline in the estimated welfare effect is a result

\footnotetext{
${ }^{26}$ In general, one should take care in interpreting these effects as causal. Female heads may prefer to live in SMSAs because of availability of services, jobs, or other factors.

${ }^{27} \mathrm{~A}$ state was included in the state sample if there were observations for at least seventy-five women over the course of the panel. These states were not selected to based on the composition of female heads versus married women. These states account for about 75 percent of total welfare caseload or about 70 percent of all white families with children.
} 
of the state effects being positively correlated with state welfare benefits for female heads of household. For example, high benefit states such as California, Minnesota and New York have high benefits and relatively large state effects. The correlation coefficient for these series is 0.36 . These results are consistent with the idea that unmeasured state effects influence white headship decisions and welfare benefits. For example, a state may have a strong two-family tradition which results in fewer female headed households and less support for the AFDC program. Not taking into account state effects attributes this difference in preferences to a welfare incentive.

In order to confirm the robustness of these results to the functional form assumption, a logit model was also estimated. These estimates, presented in Appendix Table A-1, confirm that adding state effects reduces both the magnitude and statistical significance of the welfare effect. The last specification in table A-1 adds discrete individual random effects to account for a common disturbance in the panel (Heckman and Singer 1984). These results imply that, in the absence of state effects, increasing benefits by $\$ 100$ leads to a seven percent increase in the probability of being a female head of household.

The remainder of the table provides strong evidence that for whites, state effects are capturing differences in the composition of the population across the states. Adding individual fixed effects, as shown in (5), has virtually the same impact on the estimated welfare effect as adding state fixed effects -- the coefficient on AFDC benefits becomes small (actually turns negative) and insignificant. Once individual effects are included, adding state effects do not change the parameter of interest. The state effects are still important (e.g., they are still jointly significant at the 1 percent level) but they do not influence the estimated welfare effect. This result is good news for applications when only pooled cross-sectional information is available in that controlling for state effects is sufficient to account for population heterogeneity across states.

It is worth considering more formally why we might expect state and individual effects to 
have a differential impact on the estimated welfare effect. Suppose that no families moved over the course of the PSID panel. Then controls for state of residence, through state fixed effects, would have the same influence on the welfare effect as the individual effects. This is because welfare benefits only vary by state and, in the event that no households move across states, all that we have to identify the state effects is the individual effects of its residents. In that case, we would expect specifications (4) and (5) to have the same coefficient on welfare benefits. In other words, the correlation between welfare benefits and state effects would be equal to the correlation between benefits and individual effects. We do, however, observe families moving between states in the PSID data. Among the sample of female heads of household, about 9 percent of black and 16 percent of whites move at some time over the two decades covered by the PSID. This migration implies that the composition of the population within a state is not fixed, and therefore, individual effects and state effects can have different impacts on the estimated welfare effect.

Table 4 explores the sensitivity of the estimated welfare effect to omitting determinants of state AFDC benefits. The upper panel of the table adds state economic and political variables to model (2) in table 3 with no controls for state effects. The lower panel of the table re-estimates these models with state effects. Each specification in table 4 also includes all individual and family controls used in table 3 but are omitted for brevity. ${ }^{28}$ These estimates imply that higher rates of female headship are found in states with (proportionally) fewer children, fewer elderly and more AFDC cases per capita, and states with higher unemployment rates and average wages. The political variables (dummy for republican governor and proportion of state houses held by Republicans) do not appear to be important. Despite their ability to explain variation in female headship patterns, these results do not provide strong evidence for the endogeneity of welfare benefits. Specification

\footnotetext{
${ }^{28}$ As a point of reference, the first specification table 4 drops the labor market controls that have been included in all specifications in table 3 . Thus the parameter estimates do not match.
} 
(2) in Table 4 shows that adding controls for economic variables (including AFDC caseload per capita) reduces the size of the welfare effect. This is primarily due to the inclusion of the labor market controls (unemployment rate and average wage) that were included in the earlier specifications in table 3. Adding demographic and political variables as additional policy determination variables have no impact on the estimated welfare effect. ${ }^{29,30}$

\section{Estimates for Black Women}

Results for the linear probability model are presented in table 5. The estimates for the full sample with division dummies, model (1), show that the determinants of female headship for blacks differ substantially from the estimates reported for whites. The benefit effect is significantly larger among blacks than it is for whites. For blacks, a $\$ 100$ increase in welfare benefits increases the headship probability by over two percentage points, or 7 percent. The larger welfare effect for blacks may be a result of blacks having a greater likelihood of taking up benefits as female heads. Previous studies have found greater welfare benefits for blacks (Ellwood and Bane, 1985; Moffitt, 1990a; Hoffman et al, 1991; Moffitt, 1994) as well as greater welfare effects among lower education groups within racial groups (Moffitt, 1990a; Moffitt, 1994; Winkler, 1993). The effect of other covariates is similar to that found for whites.

The state subsample for blacks contains 23749 observations in 21 states. ${ }^{31}$ Model (2) shows that the results for the state subsample do not differ substantially compared to estimates for the entire

\footnotetext{
${ }^{29}$ As noted by Besley and Case (1994), even if the omission of these state level determinants of AFDC benefits do not bias the estimated welfare effect, correlation between the unobservable elements could still lead to a bias. This is unlikely due to the lack of evidence based on observable influences.

${ }^{30}$ AFDC caseload per capita is potentially endogenous. If it is dropped from the regression the results do not change substantially.

${ }^{31}$ The state subsample for blacks contains all states with at least 50 women at some point during the panel. These states account for about 88 percent of all black families with children. The means of this subsample are presented in Appendix table B-2.
} 
sample. $^{32}$ The remaining models add state and individual effects. In sharp contrast to the estimates for whites, controlling for state effects, as shown in model (4), has almost no effect on welfare benefit estimates. The coefficient on AFDC benefits is 0.032 compared to 0.028 without any state effects. Figure 6 shows the lack of correlation between the estimated state fixed effects and average welfare benefits by state. The correlation coefficient is -0.07 . This weak negative correlation is due to a few low benefit states (Georgia, Florida) which have relatively large state effects. ${ }^{33}$

As suggested earlier, it is possible that the state effects are capturing other characteristics of the state welfare program not being captured by the welfare benefit. However, this would imply similar values for the state effects in the black and white regressions, which is not found. Among the 15 states common to the black and white state subsamples, the correlation between the state effects is weakly positive but insignificant.

The remaining specifications in table 5 show that unobserved individual effects are correlated with the state benefit level. Adding individual effects (model 5) reduces the magnitude of the welfare effect from a positive and significant 0.028 to a statistically insignificant 0.001 . By omitting a control for unobserved individual characteristics, we overestimate the role of welfare in the propensity to be a female head of household. Similarly to whites, once individual effects are included, adding state effects provides no predictive power.

There are two important points to draw from the results for blacks. First, omitting individual effects can lead-- erroneously -- to the conclusion that AFDC benefits matter for female headship decisions. The composition of black women across the states (with respect to their propensity to choose female headship) is correlated with the state welfare benefit. This can be explained by

\footnotetext{
${ }^{32}$ Because of the unequal distribution of the black population, some census divisions are poorly represented in the black state subsample. This affects the interpretation of the estimated division dummies in model (3). Accordingly, model (2) without division dummies is the base model for the state sample.

${ }^{33}$ As a specification check, these models were also estimated using a logit model with random effects. The results of the mixed logit model, presented in appendix table A-2, match the linear model results quite closely.
} 
migration to states with higher welfare benefits. Second, state effects for blacks are not correlated with welfare benefits. This is consistent with a situation in which black women are influenced by some social, cultural or religious norms at the state level (the state effects are significant) but these community norms do not affect the policy process leading to higher welfare benefits. This may be because of lack of political power in this group.

The importance of individual fixed effects can be explained by differential migration among blacks. About nine percent of black families in the sample move at some time during the twenty-two years in the PSID sample. Several facts provide evidence of differential migration. On average, these families that move are moving to higher benefit states. Those who moved found their benefits to be 1.5 percent higher than they would have been if they had stayed. Further, those with a higher propensity to be female head of household (a higher value for $\alpha_{\mathrm{i}}$ ) experience a larger increase in real benefits relative to those with a lower propensity to be a female head of household. These results imply that the positive relationship between welfare benefits and female headship that has been found in previous studies is a result of a composition effect achieved through welfare-induced migration over time. There is no evidence that of a causal relationship between welfare benefits and female headship.

This represents are very indirect way of getting at the importance of welfare benefits in migration decisions. There is, however, a sizeable literature which examines this issue and shows a modest and statistically significant effect of welfare on migration decisions (for example see recent reviews in Moffitt (1992), and Walker (1994)). The main exception is Walker (1994) who finds no evidence of migration to three high benefit states from the (locally) low benefit states with which they share borders.

Table 6 explores the robustness of these conclusions to including economic and political determinants of AFDC benefits. Again, the top panel of the table considers adding these state 
variables to the model without state effects while the bottom panel adds the state variables to the model with state effects. Similar to the results for whites, there is weak evidence of endogeneity of welfare benefits in that including the economic variables in specification (2) reduces the estimated welfare effect. Higher rates of female headship are found in states with higher unemployment rates, higher wages, and higher income. States with republican governors with more republicans in the state senate have lower rates of female headship. With state effects, however, adding the state variables have a much smaller effect.

\section{Conclusion}

This paper examines what impact unmeasured state, individual effects, and variables measuring the determinants of AFDC benefits have on estimates of the effect of welfare benefits on female headship decisions. Using over twenty years of data from the Panel Study of Income Dynamics, we specify a model of female headship that not only includes controls for characteristics of the woman, state characteristics, year effects, and welfare variables, but also controls for state of residence and individual effects. The results show that welfare benefits are positively correlated with both individual and state effects for white women. Models excluding both measures result in a positive and significant welfare effect while the model including the either effect leads to a negative (or zero) and insignificant welfare effect. That is, including individual effects has the same impact as controlling for state effects. This gives a natural interpretation to the state effects as capturing the composition of the state residents. This is good news for those applications where there is not panel data available, but pooled cross-sections are. Among blacks, however, the results are quite different. There is virtually no correlation between state effects and welfare benefits and omitting state effects has no impact on the estimated welfare effect. However, omitting the individual effects does generate a substantial bias. Once we control for individual effects, the estimated welfare effect is small and statistically insignificant. This can be explained by higher propensities for welfare induced migration 
by women with greater likelihood of becoming female heads of household, independent of the welfare system. This suggests that a study examining the determinants of inter-state migration patterns of black women would be useful.

These results have important implications for the literature on welfare and female headship. This study clearly shows that there is no evidence that AFDC benefits play any role in female headship decisions. More generally, the study also underscores the importance of close examination of results which rely on inter-state variation when the regression may contain unmeasured state effects. 


\section{References}

Bane, Mary Jo. 1986. "Household Composition and Poverty," in Sheldon Danziger and Daniel Weinberg, eds, Fighting Poverty. What Works and What Doesn't. Cambridge: Harvard University Press.

Bane, Mary Jo and David Ellwood. 1986. "Slipping Into and Out of Poverty: The Dynamics of Spells," Journal of Human Resources 21(1):1-23.

Becker, Gary. 1973. "A Theory of Marriage: Part I," Journal of Political Economy 81: 813-846. 1974. "A Theory of Marriage: Part II," Journal of Political Economy 82:511-526. 1981. A Treatise on the Family. Cambridge: Harvard University Press.

Besley, Timothy and Anne Case. 1994. "Unnatural Experiments? Estimating the Incidence of Endogenous Policies," NBER Working Paper 4956. December 1994.

Bishop, John. 1980. "Jobs, Cash Transfers and Marital Stability: A Review and Synthesis of the Evidence," Journal of Human Resources 15.

Chamberlain, Gary. 1980. "Analysis of Covariance with Qualitative Data," Review of Economic Studies 47:225-38.

Danziger, Sheldon, George Jakubson, Saul Schwartz, and Eugene Smolensky. 1982. "Work and Welfare as Determinants of Female Poverty and Household Headship, "Quarterly Journal of Economics, August.

Darity, William and Samuel Myers. 1983. "Changes in Black Family Structure: Implications for Welfare Dependency," American Economic Review.

Dechter, Aimee. 1992. "The Effect of Women's Economic Independence on Union Dissolution," mimeo.

Duncan, Greg. 1984. Years of Poverty, Years of Plenty. Ann Arbor: Institute for Social Research, The University of Michigan.

Duncan, Greg and Saul Hoffman. 1990. "Welfare Benefits, Economic Opportunities, and Out-OfWedlock Births Among Black Teenage Girls, "Demography 27(4).

Ellwood, David and Mary Jo Bane. 1985. "The Impact of AFDC on Family Structure and Living Arrangements," in Richard Ehrenberg, ed, Research in Labor Economics, Volume 7.

Ellwood, David and Jonathan Crane. 1990. "Family Change Among Black Americans: What do we Know?", Journal of Economic Perspectives 4(4):65-84.

Espenshade, Thomas. 1985. "Marriage Trends in America: Estimates, Implications, and Underlying 
Causes," Population and Development Review.

Garfinkel, Irwin and Sara McLanahan. 1986. Single Mothers and Their Children. Washington DC: The Urban Institute Press.

Groeneveld, Lyle, Michael Hannan and Nancy Tuma. 1983. Final Report of the Seattle/Denver Income Maintenance Experiment, Volume I, Design and Results. Washington DC: U.S. Government Printing Office.

Heckman, James and Burton Singer 1984. "A Method for Minimizing the Impact of Distributional Assumptions in Econometric Models for Duration Data." Econometrica 52:271-319.

Hoffman, Saul, Greg Duncan, and Ronald Mincy. 1991. "Marriage and Welfare Use Among Young Women: Do Labor Market, Welfare and Neighborhood Factors Account for Declining Rates of Marriage Among Black and White Women?", mimeo.

Hoffman, Saul and Greg Duncan. 1993. "The Effect of Incomes, Wages, and AFDC Benefits on Marital Disruption," mimeo.

1988. "A Comparison of Choice-Based Multinomial and Nested Logit Models: The Family Structure and Welfare Use Decisions of Divorced or Separated Women," Journal of Human Resources 23(4).

Hoynes, Hilary Williamson. 1995. "Welfare Transfers In Two-Parent Families: The Case of AFDCUP." Forthcoming, Econometrica.

Huber, P.J. 1967. "The Behavior of Maximum Likelihood Estimates Under Non-Standard Conditions." Proceedings of the Fifth Berkeley Symposium on Math Statistics and Probability 1:221-233.

Hutchens, Robert, George Jakubson and Saul Schwartz. 1989. "AFDC and the Formation of Subfamilies," Journal of Human Resources 24.

Maddala, G.S. 1983. Limited-Dependent and Qualitative Variables in Econometrics. Cambridge University Press.

McLanahan, Sara. 1988. "Family Structure and Dependency: Early Transitions to Female Household Headship," Demography 25(1).

Moffitt, Robert. 1990a. "The Effect of the U.S. Welfare System on Marital Status," Journal of Public Economics 41, pp. 101-124. 1990b. "Has State Distribution Policy Grown More Conservative?" National Tax Journal. 1992. "Incentive Effects of the U.S. Welfare System: A Review," Journal of Economic Literature 30, pp. 1-61. 
. 1994. "Welfare Effects on Female Headship with Area Effects," Journal of Human Resources 29(2), pp. 621-636.

Moffitt, Robert and Barbara Wolfe. 1992. "The Effect of the Medicaid Program on Welfare Participation and Labor Supply." Review of Economics and Statistics.

Murray, Charles, Losing Ground: American Social Policy, 1950-1980, New York: Basic Books, 1984.

Poterba, James. 1993. "State Responses to Fiscal Crises: The Effects of Budgetary Institutions and Politics," forthcoming in Journal of Political Economy.

Plotnick, Robert. 1990. "Welfare and Out-of-Wedlock Childbearing: Evidence from the 1980s," Journal of Marriage and the Family 52:735-746.

Plotnick, Robert and Richard Winters. 1985. "A Politico-Economic Theory of Income Redistribution," American Political Science Review, 79:458-473.

Rosenzweig, Mark and Kenneth Wolpin. 1986. "Evaluating the Effects of Optimally Distributed Public Programs," American Economic Review, 76(4):470-482.

Ross, Heather and Isabel Sawhill. 1975. Time of Transition: The Growth of Families Headed by Women. Washington DC: The Urban Institute Press.

Schultz, T. Paul. 1994. "Marital Status and Fertility in the United States: Welfare and Labor Market Effects," Journal of Human Resources 29(2), pp. 637-669.

Tsaio, Cheng. 1986. Analysis of Panel Data, Cambridge University Press.

U.S. Bureau of the Census. 1961. Household and Family Characteristics: March 1960, P-20, No, 106.

U.S. Bureau of the Census. 1991a. Household and Family Characteristics: March 1990, P-20, No, 458.

U.S. Bureau of the Census. 1991b. Poverty in the United States: 1990, P-60, No, 175.

U.S. House of Representatives. 1992. Background Materials and Data on Programs Within the Jurisdiction of the Committee on Ways and Means. Washington D.C.: Government Printing Office.

Wilson, William and Katherine Neckerman. 1986. "Poverty and Family Structure: The Widening Gap between Evidence and Public Policy Issues," in Sheldon Danziger and Daniel Weinberg, eds, Fighting Poverty. What Works and What Doesn't. Cambridge: Harvard University Press.

Winkler, Anne. 1993. "AFDC, Cohabitation and the Family Support Act of 1988," mimeo, 
University of Missouri, St- Louis. 


\section{Appendix A}

\section{Likelihood Function for Mixed Logit Model}

Assume that the individual effect $\alpha_{\mathrm{i}}$ in (5) is drawn from a discrete distribution with $K$ points of support. The points of support are given by $v_{k}$ with probability $\pi_{k}$. Further, if the distribution of the error $\epsilon_{\mathrm{its}}$ is logistic, then the probability that a woman is a female head of household given covariates $Z_{i t}$ and discrete random effect $v_{k}$ is given by $F\left(Z_{i t} B+v_{k}\right)$ where $F(x)=1 /(1+\exp (x))$. The likelihood for individual $i$, then, is given by

$$
L_{i}=\sum_{k=1}^{K} \pi_{k} \prod_{i=1}^{T} F\left(Z_{i n} \beta+v_{k}\right) \delta_{i t}\left[1-F\left(Z_{i t} \beta+v_{k}\right)\right]^{1-\delta_{i s}}
$$

where $\delta_{i t}$ is equal to 1 if individual $i$ in year $t$ is a female head of household, and zero otherwise. 
Figure 1

Female Headed Households as a Percent of All Families with Children, 1968-1990

By Race

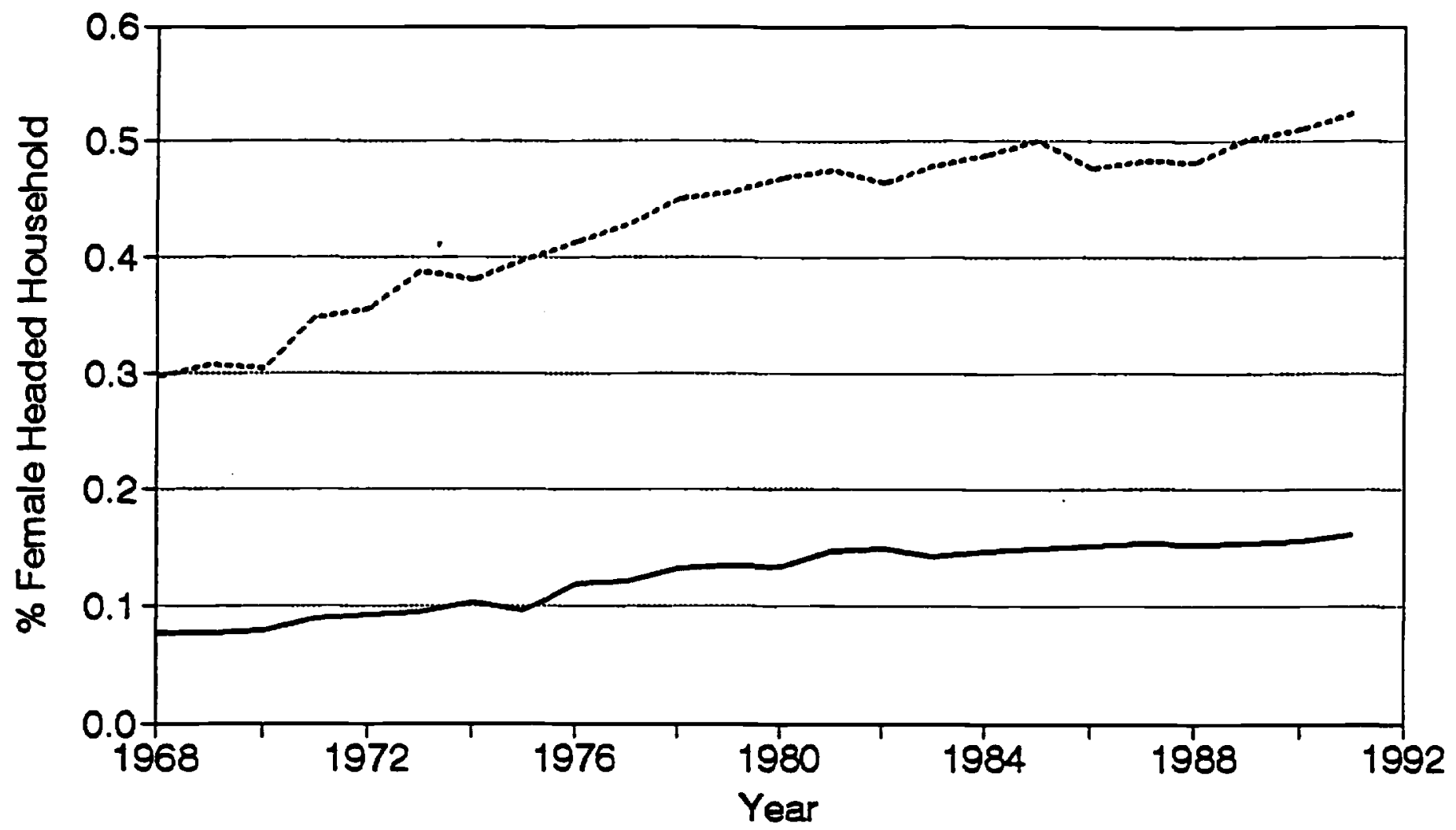

Source: U.S. Bureau of the Census, Household and Family Characteristics, various issues. 
Figure 2

Trends in Real AFDC Guarantee and Total Welfare Benefits, 1968-1989 All Races

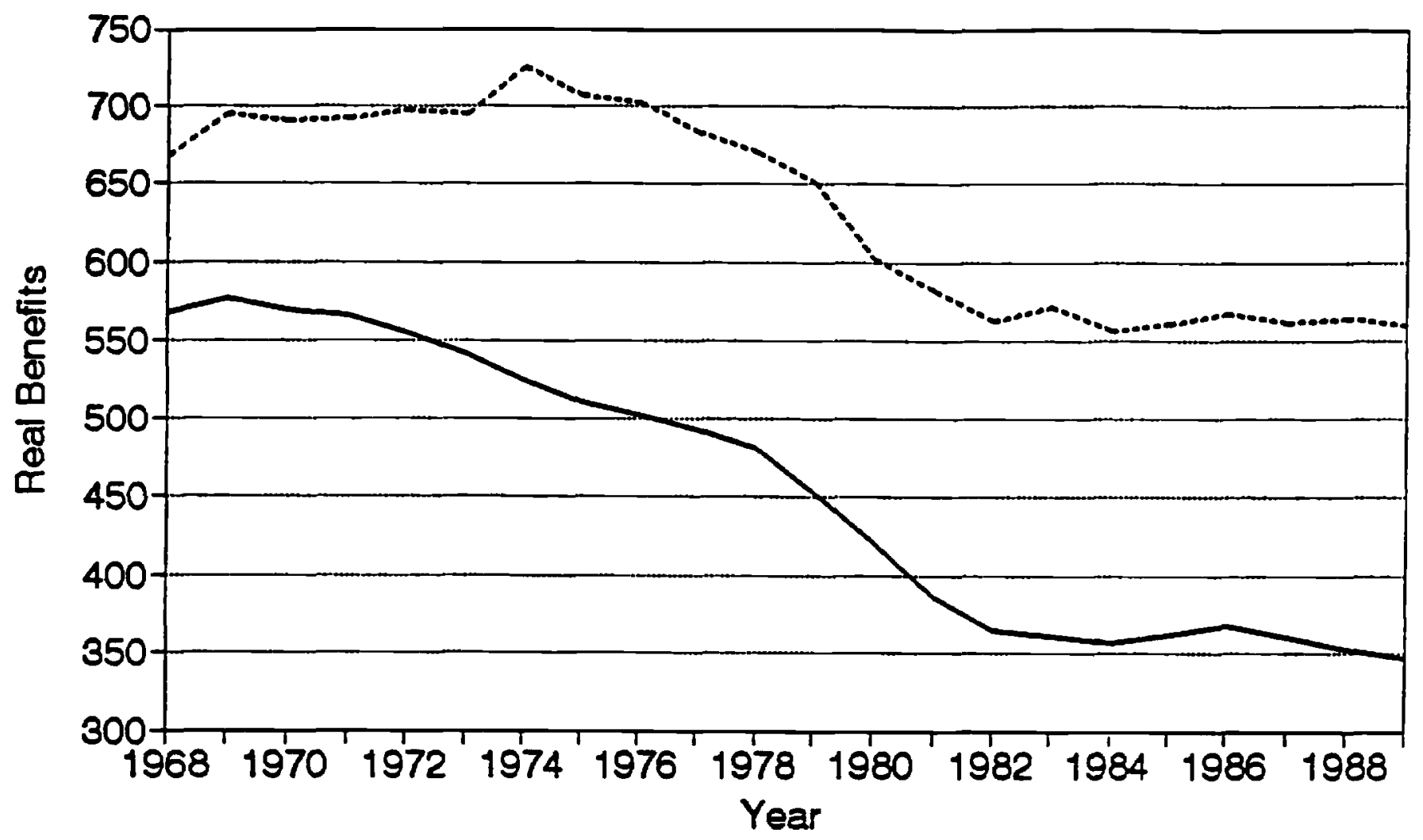

- AFDC $\quad \ldots . \cdots$ AFDC +FS + Medicaid

Source: Based on tabulations of 1968-1989 Panel Study of Income Dynamics. 
Figure 3

Trends in AFDC Benefits for Selected High Benefit States

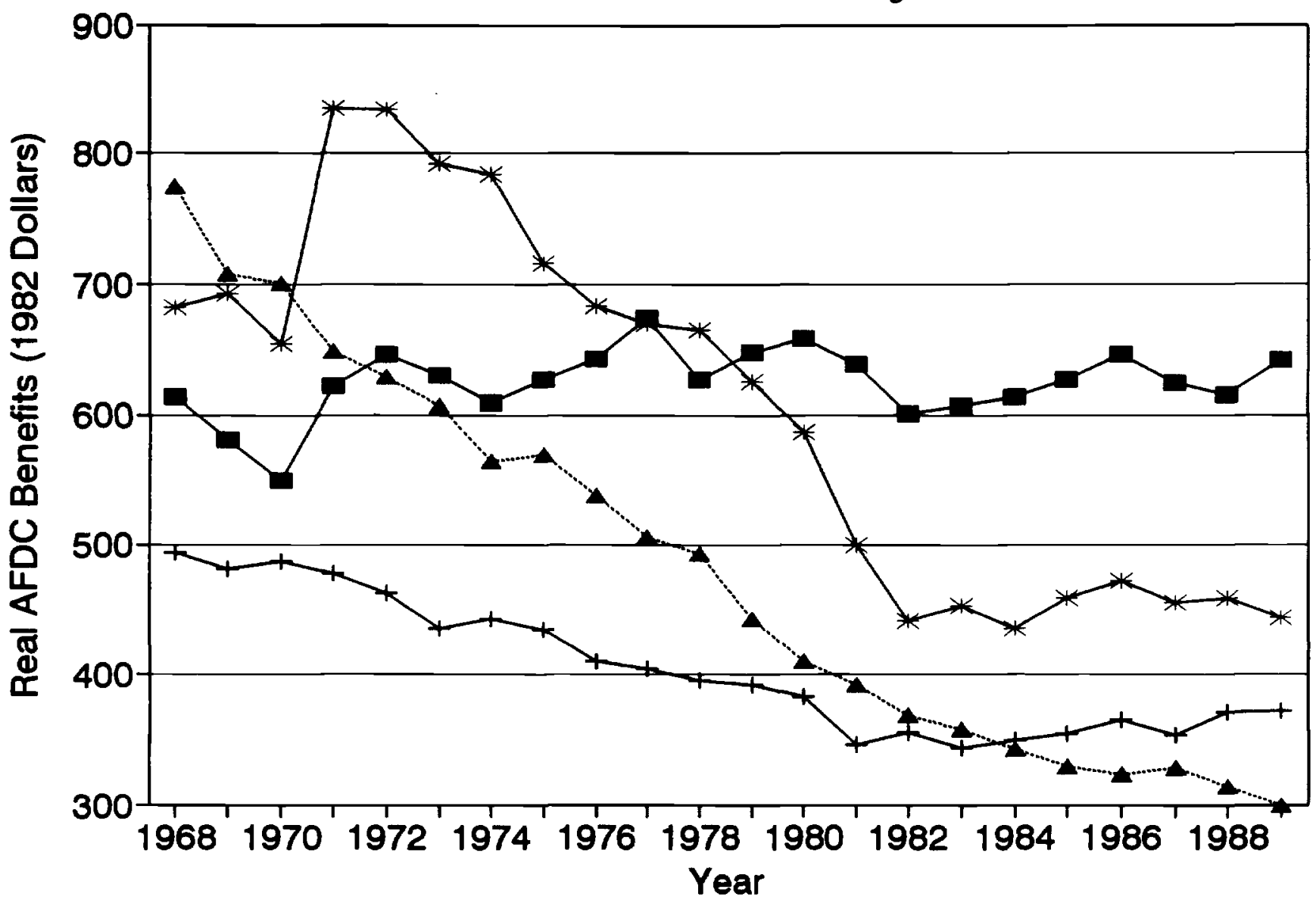

$\rightarrow-$ California $\leftarrow$ Illinois $\quad$ - Maryland $*$ Michigan 
Figure 4

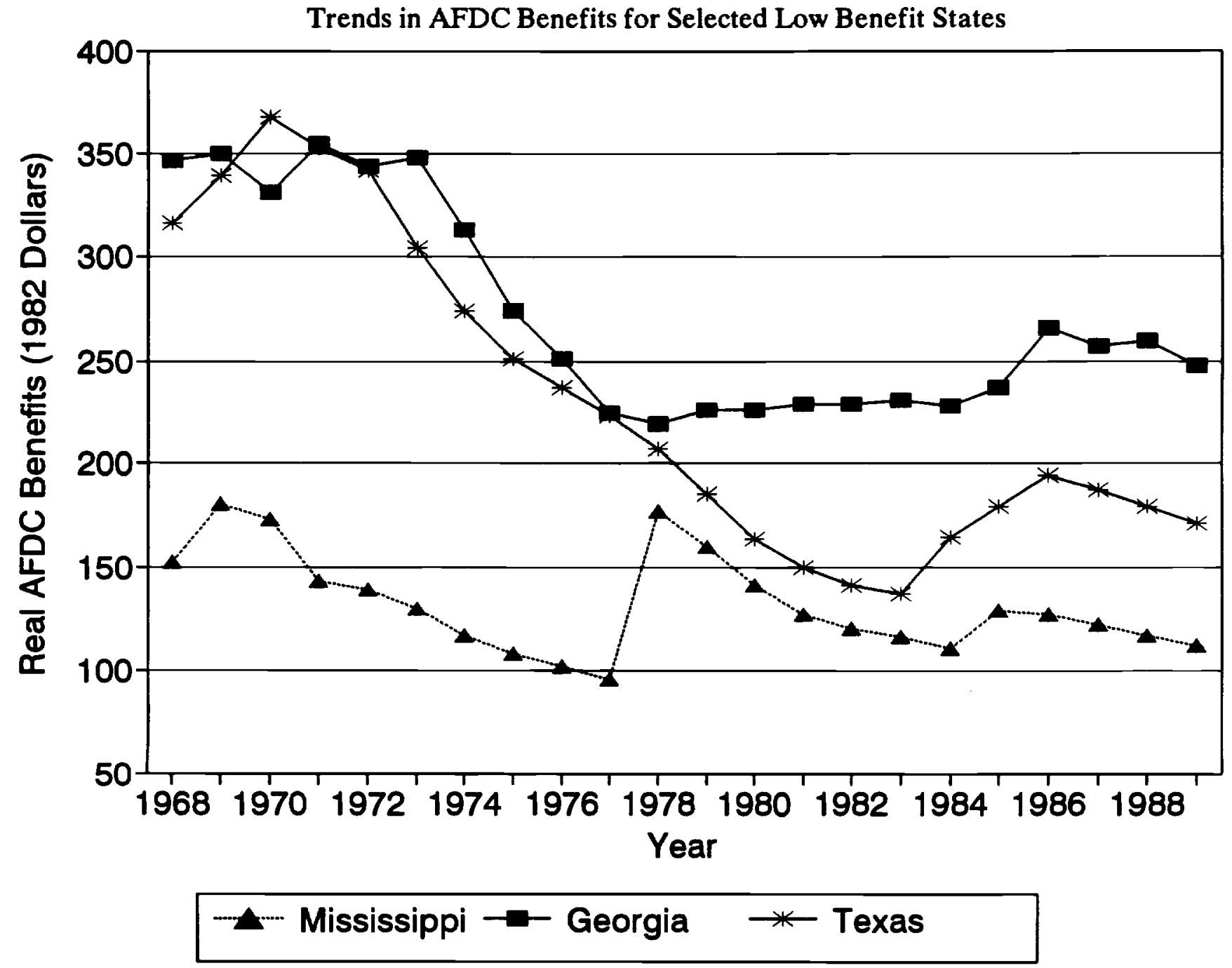


Figure 5

Correlation Between State Fixed Effects and Average Welfare Benefits

White Women

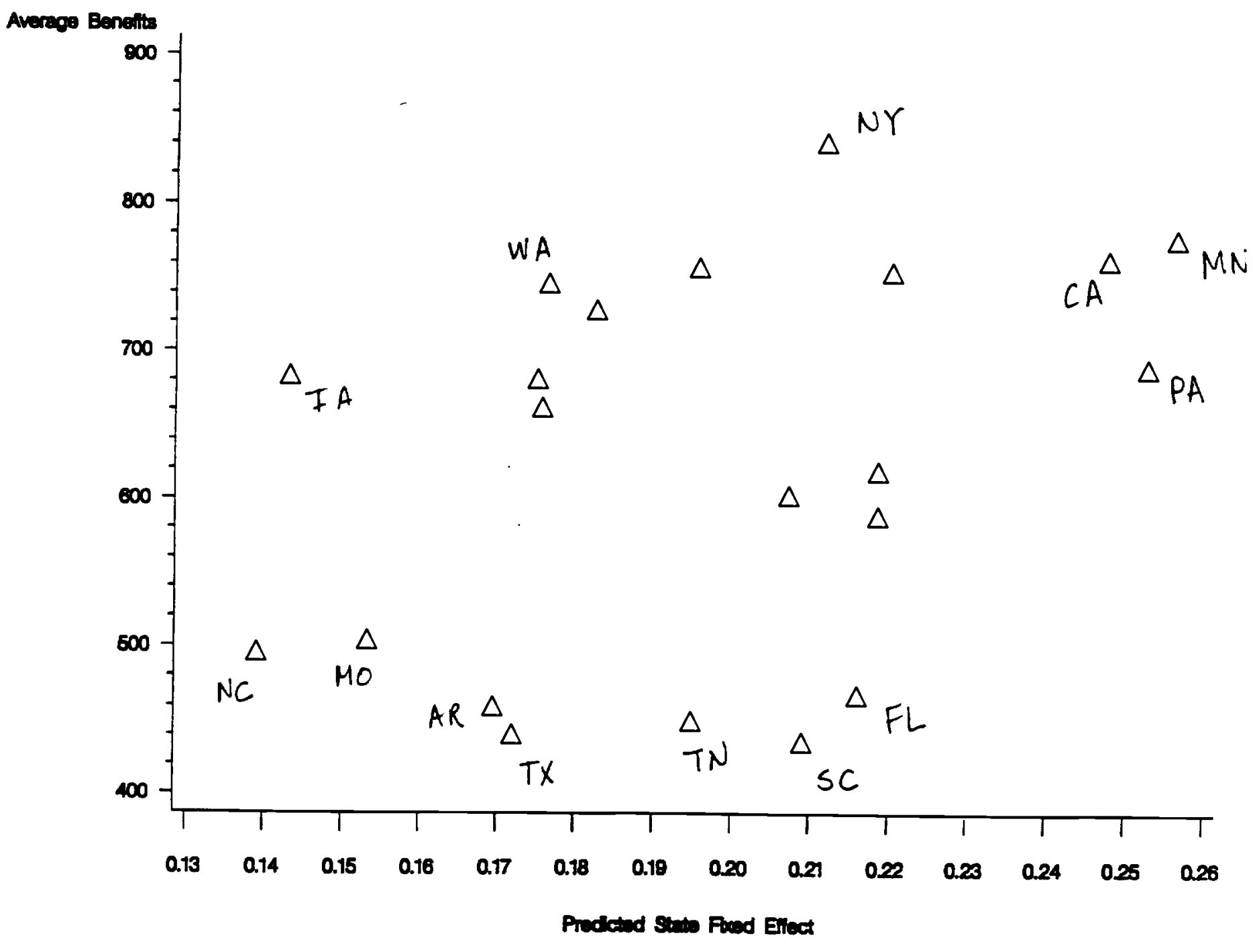

Note: Based on estimates from model (4) in Table 3 using data from the 1968-1989 Panel Study of Income Dynamics. Welfare benefits are real and are averaged over the twenty-two year period. 
Figure 6

Correlation Between State Fixed Effects and Average Welfare Benefits

Black Women

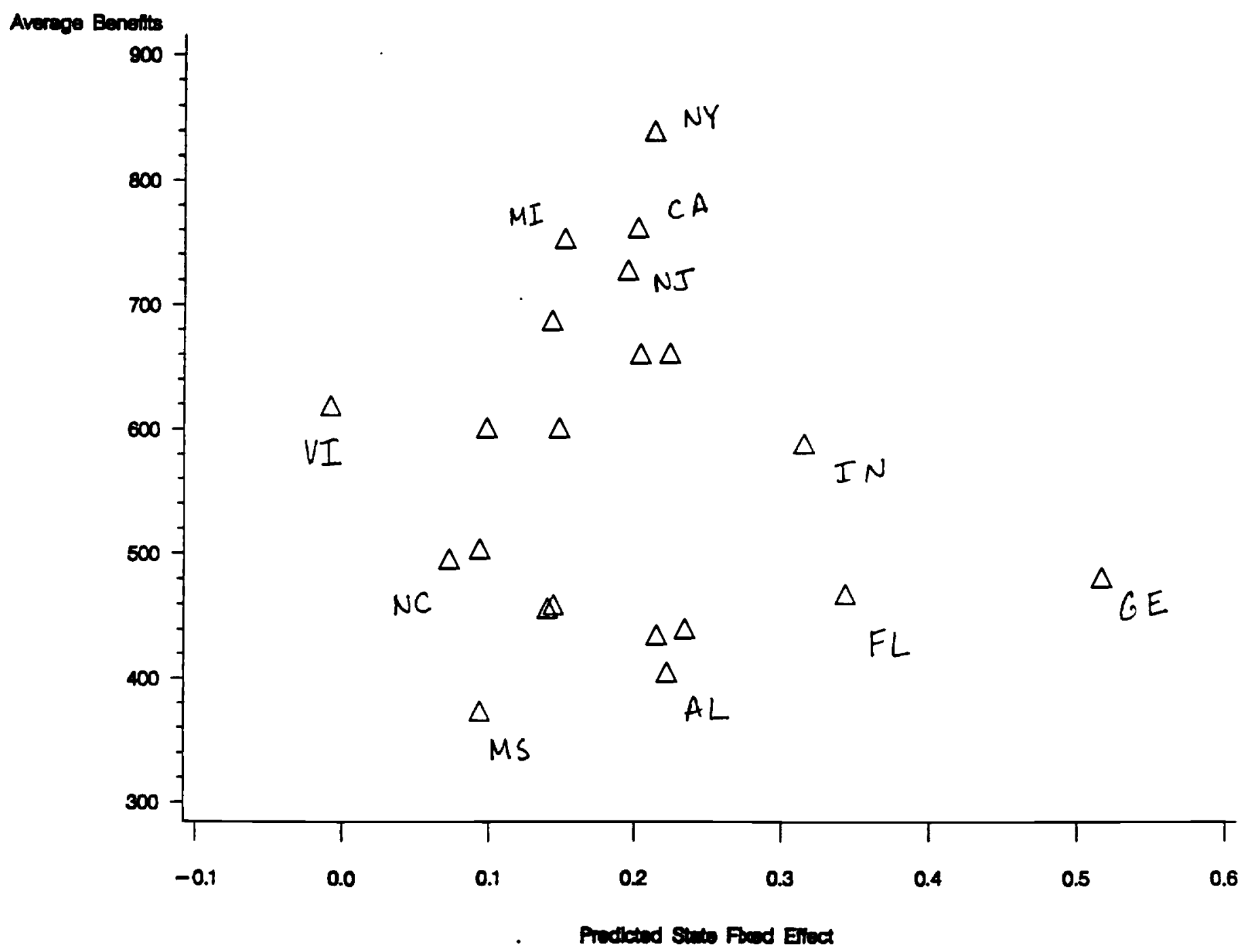

Note: Based on estimates from model (4) in Table 5 using data from the 1968-1989 Panel Study of Income Dynamics. Welfare benefits are real and are averaged over the twenty-two year period. 
Table 1

Means of PSID Sample by Female Headship Status

White Women

Female Head

Married

\begin{tabular}{|c|c|c|c|c|c|}
\hline & & Mean & $\begin{array}{l}\text { Standard } \\
\text { Deviation }\end{array}$ & Mean & $\begin{array}{l}\text { Standard } \\
\text { Deviation }\end{array}$ \\
\hline \multicolumn{2}{|l|}{ Age } & 34.031 & 8.172 & 34.316 & 7.708 \\
\hline \multirow[t]{4}{*}{ Education } & $<9$ years & 0.075 & & 0.047 & \\
\hline & 9-11 years & 0.271 & & 0.160 & \\
\hline & 12 years & 0.412 & & 0.506 & \\
\hline & $>12$ years & 0.242 & & 0.287 & \\
\hline \multicolumn{2}{|c|}{ Number of Children } & 1.851 & 1.016 & 2.117 & 1.164 \\
\hline \multirow[t]{3}{*}{ Age of You } & $<3$ & 0.188 & & 0.290 & \\
\hline & $3-5$ & 0.200 & & 0.201 & \\
\hline & $>5$ & 0.613 & & 0.509 & \\
\hline Catholic & & 0.255 & & 0.271 & \\
\hline Baptist & & 0.182 & & 0.186 & \\
\hline Protestant & & 0.363 & & 0.340 & \\
\hline Jewish & & 0.019 & & 0.039 & \\
\hline Other Relig & & 0.086 & & 0.106 & \\
\hline No Religio & & 0.114 & & 0.096 & \\
\hline SMSA & & 0.633 & & 0.600 & \\
\hline Welfare $\mathrm{Be}$ & its 1 & 637.146 & 142.774 & 641.925 & 150.719 \\
\hline AFDC-UP & & 0.640 & & 0.614 & \\
\hline Unemployr & t Rate & 6.872 & 2.271 & 6.455 & 2.267 \\
\hline Average $\mathrm{W}$ & & 8.835 & 1.184 & 8.714 & 1.178 \\
\hline State Incon & er capita $(1000)$ & 11.504 & 1.752 & 11.221 & 1.839 \\
\hline State Pop C & $65(\%)$ & 0.113 & 0.020 & 0.112 & 0.019 \\
\hline State Pop I & $(\%)$ & 0.213 & 0.028 & 0.219 & 0.030 \\
\hline State Pop E & $\mathrm{k}(\%)$ & 0.124 & 0.068 & 0.120 & 0.071 \\
\hline Rep. Gove & & 0.471 & & 0.474 & \\
\hline Rep. State & use $(\%)$ & 0.390 & 0.157 & 0.382 & 0.166 \\
\hline Rep. State & late $(\%)$ & 0.394 & 0.175 & 0.387 & 0.187 \\
\hline Number of & servations & 3942 & & 31575 & \\
\hline
\end{tabular}

1 Combined cash value of benefits from AFDC, food stamps and medicaid for a family of four. See text for details. 
Table 2

Means of PSID Sample by Female Headship Status

Black Women

\begin{tabular}{|c|c|c|c|c|c|}
\hline & & & Head & & ried \\
\hline & & Mean & $\begin{array}{l}\text { Standard } \\
\text { Deviation }\end{array}$ & Mean & $\begin{array}{l}\text { Standard } \\
\text { Deviation }\end{array}$ \\
\hline Age & & 32.433 & 8.087 & 33.456 & 8.258 \\
\hline Education & $<9$ years & 0.075 & & 0.104 & \\
\hline & 9-11 years & 0.352 & & 0.279 & \\
\hline & 12 years & 0.392 & & 0.410 & \\
\hline & $>12$ years & 0.181 & & 0.207 & \\
\hline Number of & hildren & 2.281 & 1.421 & 2.458 & 1.586 \\
\hline Age of $Y o$ & est & 0.298 & & 0.323 & \\
\hline & $3-5$ & 0.225 & & 0.234 & \\
\hline & $>5$ & 0.477 & & 0.444 & \\
\hline Catholic & & 0.055 & & 0.057 & \\
\hline Baptist & & 0.647 & & 0.610 & \\
\hline Protestant & & 0.191 & & 0.222 & \\
\hline Other Reli & & 0.022 & & 0.030 & \\
\hline No Religio & & 0.085 & & 0.081 & \\
\hline SMSA & & 0.780 & & 0.701 & \\
\hline Welfare Be & fits $\underline{1}$ & 596.246 & 155.734 & 572.618 & 151.920 \\
\hline AFDC-UP & & 0.574 & & 0.425 & \\
\hline Unemployr & t Rate & 7.001 & 2.331 & 6.423 & 2.301 \\
\hline Average $\mathrm{W}$ & & 8.610 & 1.365 & 8.198 & 1.418 \\
\hline Income per & apita (1000) & 11.397 & 1.977 & 10.60314 & 2.073 \\
\hline Percent Ag & & 0.111 & 0.018 & 0.107 & 0.019 \\
\hline Percent Ki & & 0.212 & 0.028 & 0.224 & 0.031 \\
\hline Percent Bla & & 0.187 & 0.113 & 0.199 & 0.110 \\
\hline Republican & overnor & 0.466 & & 0.415 & \\
\hline Percent Ho & Rep. & 0.331 & 0.167 & 0.277 & 0.184 \\
\hline Percent Se & Rep. & 0.334 & 0.192 & 0.274 & 0.203 \\
\hline Number of & oservations & 10542 & & 13881 & \\
\hline
\end{tabular}

1 Combined cash value of benefits from AFDC, food stamps and medicaid for a family of four. See text for details. 
Table 3

Parameter Estimates for Female Headship Model

Linear Probability Model

White Women

\begin{tabular}{c|cc}
\hline $\begin{array}{c}\text { Full Sample } \\
\text { (1) }\end{array}$ & State Sub-Sample \\
& $(2)$ & (3) \\
\hline
\end{tabular}

\begin{tabular}{|c|c|c|c|c|c|c|c|c|}
\hline Welfare Benefit & 0.006 & $(0.003)$ & 0.017 & $(0.008)$ & 0.013 & $(0.010)$ & 0.002 & $(0.006)$ \\
\hline AFDC-UP & 0.007 & $(0.009)$ & -0.006 & $(0.010)$ & -0.002 & $(0.012)$ & -0.009 & $(0.013)$ \\
\hline Age & -0.001 & $(0.001)$ & -0.002 & $(0.001)$ & -0.001 & $(0.001)$ & -0.002 & $(0.001)$ \\
\hline Education 9-11 & -0.031 & $(0.012)$ & -0.070 & $(0.026)$ & -0.043 & $(0.022)$ & -0.047 & $(0.023)$ \\
\hline Education 12 & -0.114 & $(0.012)$ & -0.153 & $(0.015)$ & -0.147 & $(0.023)$ & -0.145 & $(0.023)$ \\
\hline Education $>12$ & -0.115 & $(0.012)$ & -0.119 & $(0.030)$ & -0.151 & $(0.026)$ & -0.154 & $(0.023)$ \\
\hline Age Youngest 3-5 & 0.032 & $(0.011)$ & 0.050 & $(0.018)$ & 0.073 & $(0.020)$ & 0.050 & $(0.007)$ \\
\hline Age Youngest $>5$ & 0.068 & $(0.012)$ & 0.058 & $(0.018)$ & 0.067 & $(0.013)$ & 0.089 & $(0.008)$ \\
\hline Number of Children & -0.015 & $(0.003)$ & -0.013 & $(0.006)$ & -0.020 & $(0.004)$ & -0.022 & $(0.002)$ \\
\hline SMSA & 0.034 & $(0.007)$ & 0.045 & $(0.012)$ & 0.016 & $(0.012)$ & 0.020 & $(0.008)$ \\
\hline Baptist & 0.004 & $(0.007)$ & 0.084 & $(0.048)$ & 0.022 & $(0.014)$ & -0.005 & $(0.011)$ \\
\hline Jewish & -0.043 & $(0.008)$ & -0.055 & $(0.027)$ & -0.047 & $(0.019)$ & -0.047 & $(0.011)$ \\
\hline Protestant & 0.027 & $(0.010)$ & 0.029 & $(0.012)$ & 0.022 & $(0.017)$ & 0.003 & $(0.008)$ \\
\hline Other Religion & 0.036 & $(0.017)$ & 0.056 & $(0.037)$ & -0.024 & $(0.020)$ & -0.010 & $(0.015)$ \\
\hline No Religion & 0.014 & $(0.007)$ & 0.045 & $(0.017)$ & 0.027 & $(0.011)$ & 0.010 & $(0.008)$ \\
\hline Unemployment Rate & 0.001 & $(0.002)$ & 0.017 & $(0.007)$ & 0.001 & $(0.004)$ & 0.001 & $(0.003)$ \\
\hline Average Wage & -0.001 & $(0.007)$ & 0.001 & $(0.004)$ & -0.008 & $(0.010)$ & 0.013 & $(0.008)$ \\
\hline Intercept & 0.087 & $(0.071)$ & 0.066 & $(0.096)$ & 0.143 & $(0.108)$ & & \\
\hline Year Dummies & yes & & yes & & yes & & yes & \\
\hline Division Dummies & yes & & no & & yes & & no & \\
\hline State Dummies & no & & no & & no & & yes & \\
\hline Indi. Fixed Effects & no & & no & & no & & no & \\
\hline \# of Observations & 35517 & & 27532 & & 27532 & & 27532 & \\
\hline
\end{tabular}

Standard errors are in parentheses. 
Table 3

Parameter Estimates for Female Headship Model

Linear Probability Model

White Women - Continued

Individual Effects

(5)

$\begin{array}{rrrr}-0.002 & (0.003) & -0.002 & (0.003) \\ -0.016 & (0.006) & -0.022 & (0.007) \\ 0.002 & (0.003) & 0.002 & (0.003)\end{array}$

Education 9-11

Education 12

Education $>12$

Age Youngest 3-5

$0.033 \quad(0.004)$

$0.032(0.004)$

Age Youngest $>5$

0.050

$(0.005)$

0.049

$(0.005)$

Number of Children

$-0.009$

$(0.002)$

$-0.008$

0.022

$(0.002)$

$0.015 \quad(0.006)$

Baptist

Jewish

Protestant

Other Religion

No Religion

Unemployment Rate

Average Wage

Intercept

Year Dummies

Division Dummies

State Dummies

Indi. Fixed Effects

\# of Observations
$0.000 \quad(0.001)$

$0.003 \quad(0.003)$

$-0.001$

$(0.001)$

0.002

$(0.004)$

yes

yes

no

no

no

yes

yes

yes
(0.006)

Standard errors are in parentheses. 
Table 4

Parameter Estimates for Female Headship Model

Adding State Controls

White Women

No State Fixed Effects (Model (2) in Table 3)
(1)
(2)
(3)

(4)

\begin{tabular}{|c|c|c|c|c|c|c|c|c|}
\hline Welfare Benefit & 0.011 & $(0.003)$ & 0.007 & $(0.005)$ & 0.006 & $(0.006)$ & 0.005 & $(0.006)$ \\
\hline AFDC-UP & 0.011 & $(0.016)$ & -0.013 & $(0.009)$ & -0.013 & $(0.018)$ & -0.014 & $(0.037)$ \\
\hline Unemployment Rate & & & 0.007 & $(0.002)$ & 0.007 & $(0.004)$ & 0.007 & $(0.006)$ \\
\hline Average Wage & & & 0.007 & $(0.003)$ & 0.014 & $(0.008)$ & 0.012 & $(0.015)$ \\
\hline STINC/POP (1000) & & & 0.001 & $(0.003)$ & -0.008 & $(0.006)$ & -0.008 & $(0.007)$ \\
\hline AFDC Cases/POP & & & 2.277 & $(1.552)$ & 1.670 & $(2.126)$ & 1.985 & (1.314) \\
\hline AGED/POP & & & & & -0.695 & $(0.550)$ & -0.719 & $(0.427)$ \\
\hline KIDS/POP & & & & & -1.933 & $(0.608)$ & -1.908 & $(0.827)$ \\
\hline Rep. Governor & & & & & & & 0.000 & $(0.014)$ \\
\hline Rep. Senate (\%) & & & & & & & -0.007 & $(0.125)$ \\
\hline Rep. House (\%) & & & & & & & 0.037 & (0.095) \\
\hline Year Dummies & yes & & yes & & yes & & yes & \\
\hline \# of Observations & 27532 & & 27532 & & 27532 & & 27532 & \\
\hline
\end{tabular}

State Fixed Effects (Model (4) in Table 3)

(1)

(2)

(3)

(4)

\begin{tabular}{|c|c|c|c|c|c|c|c|c|}
\hline Welfare Benefit & 0.001 & $(0.006)$ & 0.004 & $(0.006)$ & 0.004 & $(0.005)$ & 0.003 & $(0.008)$ \\
\hline AFDC-UP & -0.016 & $(0.010)$ & -0.016 & $(0.014)$ & -0.017 & $(0.009)$ & -0.022 & $(0.016)$ \\
\hline Unemployment Rate & & & 0.005 & $(0.003)$ & 0.007 & $(0.003)$ & 0.006 & $(0.008)$ \\
\hline Average Wage & & & 0.008 & $(0.010)$ & 0.008 & $(0.012)$ & 0.007 & $(0.013)$ \\
\hline STINC/POP (1000) & & & 0.003 & $(0.010)$ & -0.003 & $(0.007)$ & -0.003 & $(0.013)$ \\
\hline AFDC Cases/POP & & & 3.377 & (1.412) & 2.611 & (1.579) & 3.205 & (2.976) \\
\hline AGED/POP & & & & & 0.376 & (1.185) & 0.569 & (1.319) \\
\hline KIDS/POP & & & & & -2.169 & (1.571) & -2.100 & $(0.589)$ \\
\hline Rep. Governor & & & & & & & 0.009 & $(0.013)$ \\
\hline Rep. Senate (\%) & & & & & & & 0.024 & $(0.103)$ \\
\hline Rep. House (\%) & & & & & & & 0.004 & $(0.192)$ \\
\hline Year Dummies & yes & & yes & & yes & & yes & \\
\hline \# of Observations & 27532 & & 27532 & & 27532 & & 27532 & \\
\hline
\end{tabular}

Standard errors are in parentheses. 
Table 5

Parameter Estimates for Female Headship Model

Linear Probability Model

Black Women

Full Sample

(1)
(2)

State Sample

(3)

\begin{tabular}{|c|c|c|c|c|c|c|c|c|}
\hline Welfare Benefit & 0.023 & $(0.008)$ & 0.032 & $(0.006)$ & 0.003 & $(0.009)$ & 0.028 & $(0.011)$ \\
\hline AFDC-UP & 0.034 & $(0.018)$ & 0.037 & $(0.018)$ & 0.027 & $(0.019)$ & 0.073 & $(0.030)$ \\
\hline Age & -0.005 & $(0.001)$ & -0.005 & $(0.001)$ & -0.004 & $(0.001)$ & -0.004 & $(0.001)$ \\
\hline Education 9-11 & 0.002 & $(0.019)$ & 0.018 & $(0.019)$ & 0.021 & $(0.020)$ & -0.004 & $(0.018)$ \\
\hline Education 12 & -0.106 & $(0.019)$ & -0.092 & $(0.019)$ & -0.077 & $(0.023)$ & -0.102 & $(0.019)$ \\
\hline Education $>12$ & -0.170 & $(0.022)$ & -0.162 & $(0.021)$ & -0.160 & $(0.023)$ & -0.175 & $(0.021)$ \\
\hline Age Youngest 3-5 & 0.017 & $(0,014)$ & 0.006 & $(0.014)$ & 0.019 & $(0.018)$ & 0.007 & $(0.014)$ \\
\hline Age Youngest $>5$ & 0.075 & $(0.014)$ & 0.074 & $(0.014)$ & 0.075 & $(0.014)$ & 0.067 & $(0.015)$ \\
\hline Number of Children & -0.003 & $(0.004)$ & -0.003 & $(0.004)$ & -0.004 & $(0.004)$ & -0.005 & $(0.003)$ \\
\hline SMSA & 0.034 & $(0.014)$ & 0.043 & $(0.014)$ & 0.045 & $(0.016)$ & -0.005 & $(0.015)$ \\
\hline Baptist & 0.012 & $(0.004)$ & 0.015 & $(0.004)$ & 0.015 & $(0.004)$ & 0.018 & $(0.005)$ \\
\hline Protestant & 0.012 & $(0.007)$ & 0.023 & $(0.006)$ & 0.022 & $(0.008)$ & 0.016 & $(0.011)$ \\
\hline Other Religion & 0.047 & $(0.023)$ & 0.047 & $(0.024)$ & 0.044 & $(0.027)$ & 0.037 & $(0.024)$ \\
\hline No Religion & 0.001 & $(0.026)$ & -0.011 & $(0.026)$ & -0.015 & $(0.028)$ & -0.027 & $(0.026)$ \\
\hline Unemployment Rate & -0.052 & $(0.047)$ & -0.094 & $(0.043)$ & 0.016 & $(0.105)$ & -0.117 & $(0.037)$ \\
\hline Average Wage & -0.023 & $(0.030)$ & -0.024 & $(0.031)$ & -0.036 & $(0.033)$ & -0.032 & $(0.030)$ \\
\hline Intercept & -0.041 & $(0.086)$ & 0.026 & $(0.061)$ & 0.281 & $(0.085)$ & & \\
\hline Year Dummies & yes & & yes & & yes & & yes & \\
\hline Division Dummies & yes & & no & & yes & & no & \\
\hline State Dummies & no & & no & & no & & yes & \\
\hline Indi. Fixed Effects & no & & no & & no & & no & \\
\hline \# of Observations & 24423 & & 23749 & & 23749 & & 23749 & \\
\hline
\end{tabular}

Standard errors are in parentheses. 
Table 5

Parameter Estimates for Female Headship Model

Linear Probability Model

Black Women - Continued

Individual Effects

(5)

State and Individual Effects

(6)

\begin{tabular}{|c|c|c|c|c|}
\hline Welfare Benefit & 0.002 & $(0.004)$ & -0.003 & $(0.004)$ \\
\hline AFDC-UP & -0.012 & $(0.009)$ & -0.011 & $(0.010)$ \\
\hline Age & 0.003 & $(0.003)$ & 0.003 & $(0.003)$ \\
\hline \multicolumn{5}{|l|}{ Education 9-11 } \\
\hline \multicolumn{5}{|l|}{ Education 12} \\
\hline \multicolumn{5}{|l|}{ Education $>12$} \\
\hline Age Youngest 3-5 & 0.010 & $(0.004)$ & 0.008 & $(0.004)$ \\
\hline Age Youngest $>5$ & 0.017 & $(0.005)$ & 0.017 & $(0.005)$ \\
\hline Number of Children & -0.003 & $(0.002)$ & -0.005 & $(0.002)$ \\
\hline SMSA & -0.015 & $(0.009)$ & 0.004 & $(0.010)$ \\
\hline \multicolumn{5}{|l|}{ Baptist } \\
\hline \multicolumn{5}{|l|}{ Protestant } \\
\hline \multicolumn{5}{|l|}{ Other Religion } \\
\hline \multicolumn{5}{|l|}{ No Religion } \\
\hline Unemployment Rate & 0.001 & $(0.002)$ & 0.004 & $(0.002)$ \\
\hline Average Wage & -0.003 & $(0.004)$ & 0.003 & $(0.004)$ \\
\hline \multicolumn{5}{|l|}{ Intercept } \\
\hline Year Dummies & yes & & yes & \\
\hline Division Dummies & no & & no & \\
\hline State Dummies & no & & yes & \\
\hline Indi. Fixed Effects & yes & & yes & \\
\hline \# of Observations & 23749 & & 23749 & \\
\hline
\end{tabular}

Standard errors are in parentheses. 


\section{Table 6}

Parameter Estimates for Female Headship Model

Adding State Controls

Black Women

No State Fixed Effects (Model (2) in Table 5)

(1)

\begin{tabular}{|c|c|c|c|c|c|c|c|}
\hline Welfare Benefit & 0.044 & $(0.006)$ & 0.027 & $(0.008)$ & 0.028 & $(0.008)$ & $0.020 \quad(0.008)$ \\
\hline AFDC-UP & 0.051 & $(0.017)$ & 0.028 & $(0.020)$ & 0.025 & $(0.020)$ & $0.038 \quad(0.021)$ \\
\hline Unemployment Rate & & & 0.022 & $(0.005)$ & 0.021 & $(0.005)$ & $0.026(0.005)$ \\
\hline Average Wage & & & 0.017 & $(0.006)$ & 0.018 & $(0.006)$ & $-0.004 \quad(0.007)$ \\
\hline STINC/POP (1000) & & & 0.013 & $(0.007)$ & 0.013 & $(0.007)$ & $0.029 \quad(0.009)$ \\
\hline AFDC Cases/POP & & & -0.063 & $(1.340)$ & 0.210 & (1.188) & $-1.725 \quad(1.746)$ \\
\hline AGED/POP & & & & & 0.446 & $(0.390)$ & $0.613(0.451)$ \\
\hline KIDS/POP & & & & & 0.231 & $(0.492)$ & $2.838 \quad(0.877)$ \\
\hline Rep. Governor & & & & & & & $-0.024 \quad(0.014)$ \\
\hline Rep. Senate (\%) & & & & & & & $-0.006 \quad(0.111)$ \\
\hline Rep. House (\%) & & & & & & & $0.266 \quad(0.119)$ \\
\hline Year Dummies & yes & & yes & & yes & & yes \\
\hline \multirow[t]{3}{*}{ \# of Observations } & 23749 & & 23749 & & 23749 & & 23749 \\
\hline & \multicolumn{7}{|c|}{ State Fixed Effects (Model (4) in Table 5) } \\
\hline & \multicolumn{2}{|c|}{ (1) } & \multicolumn{2}{|c|}{ (2) } & \multicolumn{2}{|c|}{ (3) } & (4) \\
\hline Welfare Benefit & 0.038 & $(0.012)$ & 0.033 & $3(0.011)$ & 0.030 & $(0.013)$ & $0.028(0.010)$ \\
\hline AFDC-UP & 0.062 & $(0.036)$ & 0.081 & $(0.032)$ & 0.087 & $(0.034)$ & $0.085(0.032)$ \\
\hline Unemployment Rate & & & 0.020 & $(0.006)$ & 0.018 & $(0.008)$ & $0.017(0.004)$ \\
\hline Average Wage & & & 0.008 & $3(0.011)$ & 0.005 & $(0.012)$ & $0.003(0.011)$ \\
\hline STINC/POP (1000) & & & 0.001 & $(0.001)$ & 0.000 & $(0.002)$ & $-0.001(0.001)$ \\
\hline AFDC Cases/POP & & & -3.084 & $(2.417)$ & -3.287 & $(2.597)$ & $-6.874(2.174)$ \\
\hline AGED/POP & & & & & -2.613 & $(1.450)$ & $-2.188(1.177)$ \\
\hline KIDS/POP & & & & & -1.010 & (1.513) & $-0.695(0.770)$ \\
\hline Rep. Governor & & & & & & & $-0.012(0.013)$ \\
\hline Rep. Senate (\%) & & & & & & & $-0.430(0.141)$ \\
\hline Rep. House (\%) & & & & & & & $0.360(0.139)$ \\
\hline Year Dummies & yes & & yes & & yes & & yes \\
\hline \# of Observations & 23749 & & 23749 & & 23749 & & 23749 \\
\hline
\end{tabular}

Standard errors are in parentheses. 
Table A-1

Parameter Estimates for Female Headship Model

Mixed Logit Model

White Women

(1)

(2)

(3)

(4)

\begin{tabular}{lrrrrrrrr}
\hline Welfare Benefit & 0.098 & $(0.018)$ & 0.060 & $(0.021)$ & 0.012 & $(0.032)$ & $0.010(0.040)$ \\
AFDC-UP & -0.002 & $(0.048)$ & 0.036 & $(0.056)$ & -0.045 & $(0.089)$ & $-0.095(0.137)$ \\
Age & -0.036 & $(0.002)$ & -0.036 & $(0.003)$ & -0.034 & $(0.003)$ & $-0.037(0.003)$ \\
Education 9-11 & -0.314 & $(0.074)$ & -0.308 & $(0.076)$ & -0.273 & $(0.076)$ & $-0.277(0.072)$ \\
Education 12 & -1.213 & $(0.071)$ & -1.197 & $(0.073)$ & -1.142 & $(0.074)$ & $-1.225(0.071)$ \\
Education >12 & -1.236 & $(0.075)$ & -1.206 & $(0.077)$ & -1.150 & $(0.078)$ & $-1.271(0.077)$ \\
Age Youngest 3-5 & 0.598 & $(0.051)$ & 0.598 & $(0.051)$ & 0.592 & $(0.051)$ & $-0.631(0.106)$ \\
Age Youngest >5 & 0.925 & $(0.049)$ & 0.920 & $(0.049)$ & 0.907 & $(0.050)$ & $0.971(0.073)$ \\
Number of Children & -0.245 & $(0.016)$ & -0.242 & $(0.016)$ & -0.245 & $(0.016)$ & $-0.254(0.019)$ \\
SMSA & 0.231 & $(0.034)$ & 0.220 & $(0.034)$ & 0.161 & $(0.035)$ & $0.187(0.039)$ \\
Baptist & 0.201 & $(0.053)$ & 0.182 & $(0.054)$ & 0.161 & $(0.056)$ & $0.056(0.022)$ \\
Jewish & -0.592 & $(0.104)$ & -0.617 & $(0.105)$ & -0.545 & $(0.107)$ & $0.094(0.089)$ \\
Protestant & 0.212 & $(0.041)$ & 0.199 & $(0.042)$ & 0.161 & $(0.043)$ & $0.188(0.056)$ \\
Other Religion & 0.125 & $(0.072)$ & 0.097 & $(0.074)$ & 0.071 & $(0.075)$ & $-0.637(0.117)$ \\
No Religion & 0.332 & $(0.055)$ & 0.299 & $(0.056)$ & 0.272 & $(0.057)$ & $0.150(0.043)$ \\
Unemployment Rate & 0.078 & $(0.013)$ & 0.050 & $(0.014)$ & 0.060 & $(0.015)$ & $0.068(0.080)$ \\
Average Wage & 0.044 & $(0.018)$ & 0.088 & $(0.031)$ & 0.100 & $(0.054)$ & $0.291(0.055)$ \\
Intercept & -1.859 & $(0.210)$ & -2.153 & $(0.313)$ & & & \\
Year Dummies & yes & & yes & & yes & & yes \\
Division Dummies & no & & yes & & no & & no \\
State Dummies & no & & no & & yes & & yes \\
Random Ind. Effects & no & & no & & no & & yes \\
Log Likelihood & -10293 & & -10270 & & -10177 & & -10084 \\
\# of Observations & 27532 & & 27532 & & 27532 & & 27532 \\
\hline
\end{tabular}

Standard errors are in parentheses. 
Table A-2

Parameter Estimates for Female Headship Model

Mixed Logit Model

Black Women

(1)

(2)

(3)

(4)

\begin{tabular}{lrrrrrrrr}
\hline Welfare Benefit & 0.157 & $(0.008)$ & 0.048 & $(0.014)$ & 0.158 & $(0.025)$ & $0.087(0.044)$ \\
AFDC-UP & 0.138 & $(0.022)$ & 0.088 & $(0.034)$ & 0.303 & $(0.138)$ & $0.434(0.201)$ \\
Age & -0.021 & $(0.001)$ & -0.022 & $(0.002)$ & -0.024 & $(0.002)$ & $-0.007(0.004)$ \\
Education 9-11 & 0.093 & $(0.035)$ & 0.095 & $(0.042)$ & 0.016 & $(0.044)$ & $0.024(0.085)$ \\
Education 12 & -0.402 & $(0.035)$ & -0.395 & $(0.042)$ & -0.481 & $(0.044)$ & $-0.514(0.087)$ \\
Education > 12 & -0.718 & $(0.037)$ & -0.734 & $(0.044)$ & -0.843 & $(0.047)$ & $-0.840(0.095)$ \\
Age Youngest 3-5 & 0.018 & $(0.022)$ & 0.021 & $(0.072)$ & 0.020 & $(0.075)$ & $0.118(0.108)$ \\
Age Youngest >5 & 0.339 & $(0.021)$ & 0.358 & $(0.042)$ & 0.387 & $(0.044)$ & $0.454(0.071)$ \\
Number of Children & -0.033 & $(0.006)$ & -0.034 & $(0.008)$ & -0.035 & $(0.009)$ & $-0.072(0.018)$ \\
SMSA & 0.168 & $(0.021)$ & 0.162 & $(0.025)$ & -0.037 & $(0.030)$ & $-0.089(0.057)$ \\
Unemployment Rate & 0.148 & $(0.035)$ & 0.085 & $(0.009)$ & 0.070 & $(0.014)$ & $0.087(0.023)$ \\
Average Wage & -0.110 & $(0.038)$ & 0.074 & $(0.016)$ & 0.060 & $(0.067)$ & $0.060(0.090)$ \\
Baptist & -0.502 & $(0.054)$ & 0.075 & $(0.041)$ & 0.075 & $(0.043)$ & $0.009(0.092)$ \\
Protestant & -0.153 & $(0.041)$ & -0.203 & $(0.043)$ & -0.239 & $(0.046)$ & $-0.189(0.101)$ \\
Other Religion & 0.075 & $(0.005)$ & -0.633 & $(0.075)$ & -0.668 & $(0.085)$ & $-0.408(0.195)$ \\
No Religion & 0.099 & $(0.009)$ & -0.286 & $(0.052)$ & -0.242 & $(0.054)$ & $-0.489(0.109)$ \\
Intercept & -2.076 & $(0.098)$ & -0.782 & $(0.357)$ & & & \\
Year Dummies & yes & & yes & yes & yes \\
Division Dummies & no & & yes & no & no \\
State Dummies & no & & no & yes & yes \\
Random Indi. Effects & no & & no & -15459 & -15091 & no & yes \\
Log Likelihood & -15662 & & 23749 & 23749 & 23749 \\
\# of Observations & 23749 & & & & & & \\
\hline & & & & & & & \\
\hline
\end{tabular}

Standard errors are in parentheses. 
Table B-1

Means of State Sample by Female Headship Status

White Women

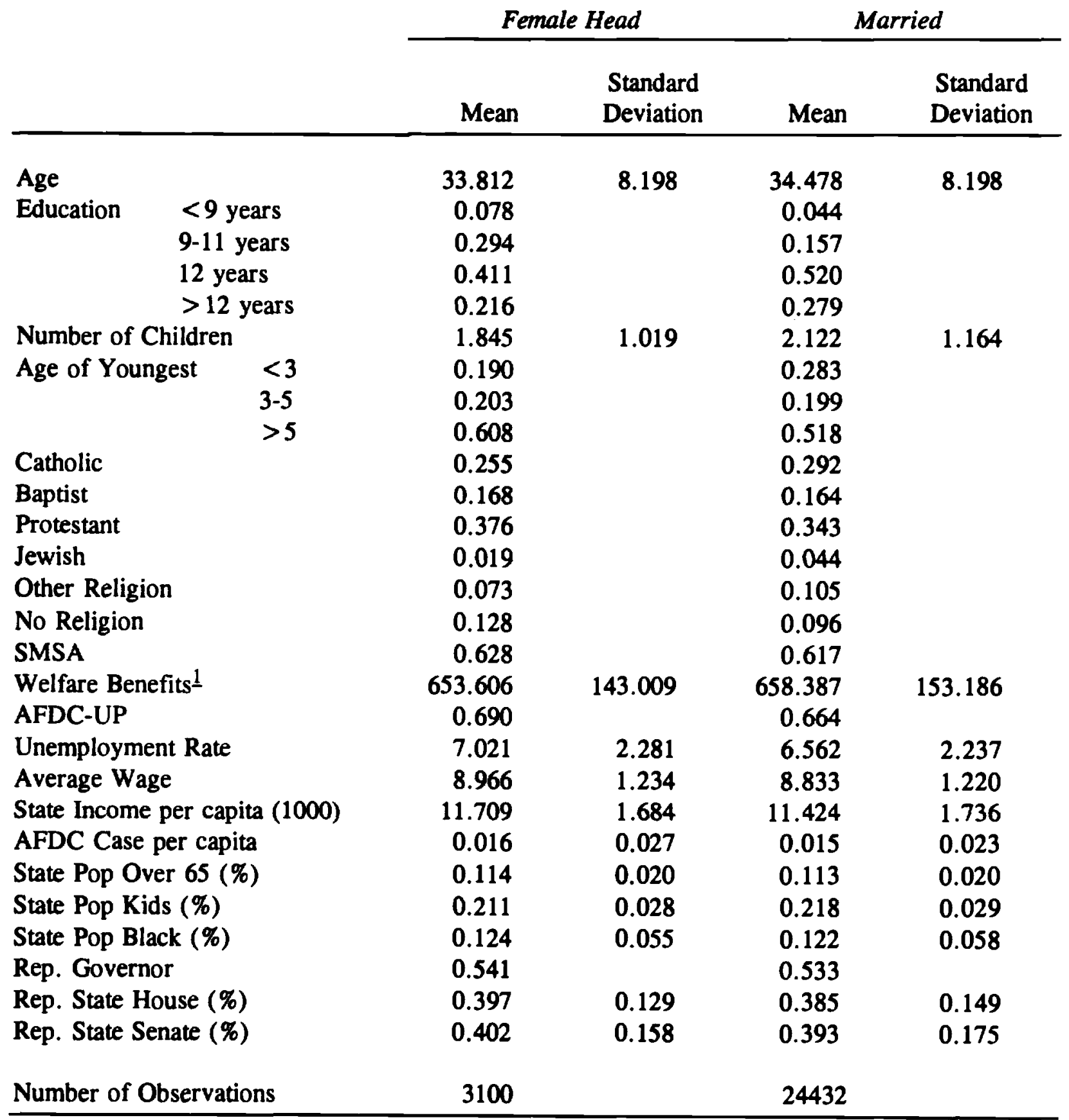

1 Combined cash value of benefits from AFDC, food stamps and medicaid for a family of four. See text for details. 
Table B-2

Means of State Sample by Female Headship Status

Black Women

Female Head

Married

\begin{tabular}{|c|c|c|c|c|c|}
\hline & & Mean & $\begin{array}{l}\text { Standard } \\
\text { Deviation }\end{array}$ & Mean & $\begin{array}{l}\text { Standard } \\
\text { Deviation }\end{array}$ \\
\hline Age & & 32.446 & 8.070 & 33.318 & 8.216 \\
\hline Education & $<9$ years & 0.075 & & 0.105 & \\
\hline & 9-11 years & 0.361 & & 0.285 & \\
\hline & 12 years & 0.387 & & 0.401 & \\
\hline & $>12$ years & 0.177 & & 0.210 & \\
\hline Number of & hildren & 2.286 & 1.432 & 2.487 & 1.597 \\
\hline Age of Yo & gest & 0.301 & & 0.326 & \\
\hline & $3-5$ & 0.220 & & 0.240 & \\
\hline & $>5$ & 0.478 & & 0.434 & \\
\hline Catholic & & 0.057 & & 0.057 & \\
\hline Baptist & & 0.655 & & 0.611 & \\
\hline Protestant & & 0.183 & & 0.219 & \\
\hline Other Reli & & 0.020 & & 0.030 & \\
\hline No Religio & & 0.085 & & 0.083 & \\
\hline SMSA & & 0.775 & & 0.696 & \\
\hline Welfare $\mathrm{Be}$ & fits 1 & 594.921 & 156.655 & 571.309 & 152.570 \\
\hline AFDC-UP & & 0.572 & & 0.426 & \\
\hline Unemployı & at Rate & 7.066 & 2.328 & 6.447 & 2.301 \\
\hline Average $\mathrm{W}$ & & 8.615 & 1.385 & 8.194 & 1.444 \\
\hline Income pes & apita (1000) & 11.428 & 1.986 & 10.633 & 2.076 \\
\hline AFDC Cas & per Capita & 0.016 & 0.014 & 0.015 & 0.012 \\
\hline Percent Ag & & 0.110 & 0.018 & 0.106 & 0.019 \\
\hline Percent Ki & & 0.212 & 0.028 & 0.224 & 0.031 \\
\hline Percent Bl & & 0.193 & 0.133 & 0.204 & 0.109 \\
\hline Republican & overnor & 0.473 & & 0.416 & \\
\hline Percent $\mathrm{Ho}$ & Rep. & 0.329 & 0.168 & 0.274 & 0.186 \\
\hline Percent Se & Rep. & 0.332 & 0.193 & 0.271 & 0.206 \\
\hline Number of & oservations & 10237 & & 13512 & \\
\hline
\end{tabular}

1 Combined cash value of benefits from AFDC, food stamps and medicaid for a family of four. See text for details. 